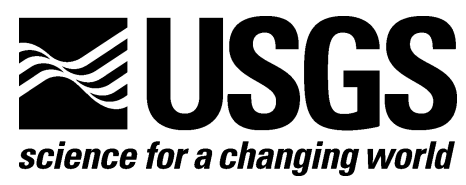

\title{
Southern Salish Sea Habitat Map Series: Admiralty Inlet
}

By Guy R. Cochrane, Megan N. Dethier, Timothy O. Hodson, Kristine J. Kull, Nadine E. Golden, Andrew C. Ritchie, Crescent H. Moegling, and Robert E. Pacunski

(Guy R. Cochrane, editor)

Pamphlet to accompany

Open-File Report 2015-1073

U.S. Department of the Interior

U.S. Geological Survey 


\section{U.S. Department of the Interior \\ SALLY JEWELL, Secretary}

U.S. Geological Survey
Suzette M. Kimball, Acting Director

U.S. Geological Survey, Reston, Virginia: 2015

For more information on the USGS—-the Federal source for science about the Earth, its natural and living resources, natural hazards, and the environment-visit http://www.usgs.gov or call 1-888-ASK-USGS

For an overview of USGS information products, including maps, imagery, and publications, visit http://www.usgs.gov/pubprod

To order this and other USGS information products, visit http://store.usgs.gov

Suggested citation:

Cochrane, G.R., Dethier, M.N., Hodson, T.O., Kull, K.J., Golden, N.E., Ritchie A.C., Moegling, C.H., and Pacunski, R.E., (G.R. Cochrane, ed.), 2015, Salish Sea Map Series-Admiralty Inlet, Washington: U.S. Geological Survey Open-File Report 2015-1073, 34 p., 4 sheets, available at http://dx.doi.org/10.3133/ofr20151073.

Any use of trade, product, or firm names is for descriptive purposes only and does not imply endorsement by the U.S. Government.

Although this report is in the public domain, permission must be secured from the individual copyright owners to reproduce any copyrighted material contained within this report. 


\section{Contents}

Introduction

By Guy R. Cochrane

Bathymetry Map (Sheet 1)

By Andrew C. Ritchie, Guy R. Cochrane, and Crescent H. Moegling

Ground-Truth Studies for the Admiralty Inlet Map Area. 8

By Guy R. Cochrane, Andrew C. Ritchie, Kristine J. Kull, Nadine E. Golden, and Robert E. Pacunski

CMECS Geoform and Substrate Maps (Sheet 2 and 3).....

By Timothy O. Hodson, Guy R. Cochrane, Andrew C. Ritchie, and Crescent H. Moegling

Biotopes (Sheet 4)

By Megan N. Dethier, Guy R. Cochrane, and Kristine J. Kull

Methods.

Results

CMECS Classification

References Cited

By Guy R. Cochrane, Megan N. Dethier, and Timothy O. Hodson

\section{Figures}

Figure 1. Location of the Southern Salish Sea map areas.

Figure 2. Areas of National Oceanic and Atmospheric Administration surveys used to create map area digital elevation model

Figure 3. Photograph of one of three different camera sleds used in U.S. Geological Survey ground-truth surveys for the Southern Salish Sea Mapping Project .................................................................................. 8

Figure 4. Video and sampling sites in the Admiralty Inlet map area ............................................................

Figure 5. Graph showing distribution of primary and secondary substrate determined from video observations

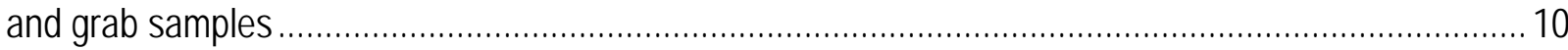

Figure 6. Numbers of samples in each depth and primary substrate type in Admiralty Inlet map area.................. 15

Figure 7. Taxa richness for Admiralty Inlet map area sample units ................................................................ 15

Figure 8. Percent of samples in different depths and substrates in the Admiralty Inlet map area........................17

Figure 9. Admiralty Inlet map area biota with samples coded by biotic communities.......................................2 20

Figure 10. Multidimensional scaling plots of Admiralty Inlet map area biotic communities ................................... 21

Figure 11. Proportion of total samples containing four key taxa by $A$, depth or $B$, CMECS substrate subclass ........ 25

Figure 12. Draftsman plot showing correlations between the six physical variables ..........................................26

Figure 13. Multidimensional scaling plot of the six physical parameters in Admiralty Inlet map area .......................28

Figure 14. Multidimensional scaling plot of physical parameters in Admiralty Inlet map area samples, with each sample coded by biological cluster group.....

\section{Tables}

Table 1. Taxa found in the Admiralty Inlet map area and their frequencies of observation............................... 18

Table 2. Results of SIMPER test for biotic assemblage similarities............................................................... 22

Table 3. Correlations between physical variables in the Admiralty Inlet map area ........................................... 27 


\section{Map Sheets}

Sheet 1. Bathymetry Map of the of Admiralty Inlet Map Area, Washington

By Andrew C. Ritchie, Guy R. Cochrane, and Crescent H. Moegling

Sheet 2. CMECS Geoform Component Map of the Admiralty Inlet Map Area, Washington

By Timothy O. Hodson, Guy R. Cochrane, Andrew C. Ritchie, and Crescent H. Moegling

Sheet 3. CMECS Substrate Component Map of the Admiralty Inlet Map Area, Washington

By Timothy O. Hodson, Guy R. Cochrane, Andrew C. Ritchie, and Crescent H. Moegling

Sheet 4. CMECS Biotope Component Map of the Admiralty Inlet Map Area, Washington

By Megan N. Dethier, Guy R. Cochrane, Timothy O. Hodson, Kristine J. Kull 


\title{
Southern Salish Sea Habitat Map Series: Admiralty Inlet
}

By Guy R. Cochrane, ${ }^{1}$ Megan N. Dethier, ${ }^{2}$ Timothy O. Hodson, ${ }^{3}$ Nadine E. Golden, ${ }^{1}$ Andrew C. Ritchie, ${ }^{4}$ Kristine J. Kull, ${ }^{2}$ Crescent H. Moegling, ${ }^{5}$ and Robert E. Pacunski 6

(Guy R. Cochrane,1 editor)

\section{Introduction}

\author{
By Guy R. Cochrane
}

In 2010 the Environmental Protection Agency, Region 10 initiated the Puget Sound Scientific Studies and Technical Investigations Assistance Program, designed to support research in support of implementing the Puget Sound Action Agenda. The Action Agenda was created in response to Puget Sound having been designated as one of 28 estuaries of national significance under section 320 of the U.S. Clean Water Act, and its overall goal is to restore the Puget Sound Estuary's environment by 2020. The Southern Salish Sea Mapping Project was funded by the Assistance Program request for proposals process, which also supports a large number of coastal-zone- and ocean-management issues. The issues include the recommendations of the Marine Protected Areas Work Group to the Washington State Legislature (Van Cleve and others, 2009), which endorses a Puget Sound and coast-wide marine conservation needs assessment, gap analysis of existing Marine Protected Areas (MPA) and recommendations for action. This publication is the first of four U.S. Geological Survey Scientific Investigation Maps that make up the Southern Salish Sea Mapping Project. The remaining three map blocks to be published in the future, located south of Admiralty Inlet, are shown in figure 1.

Puget Sound is a deep, fjord-type estuary covering an area of $2,330 \mathrm{~km}^{2}$ in the Pacific Northwest region of the United States (fig. 1). It is connected to the ocean by the Strait of Juan de Fuca, a turbulent passage approximately $160 \mathrm{~km}$ in length and $22 \mathrm{~km}$ wide at its west end, expanding to over $40 \mathrm{~km}$ wide at its east end (Thomson, 1994). During the Pleistocene, the area was occupied several times by lobes of continental ice, resulting in a complex basin-fill of glacial and interglacial deposits that are locally as thick as $1100 \mathrm{~m}$ (Johnson and others, 2001). The last glaciation, called the Fraser glaciation, began after $28,800 \pm 740{ }^{14} \mathrm{C}$ yr B.P. when ice started a slow expansion (Clague, 1981). At peak advance the westward Juan de Fuca lobe reached the edge of the continental shelf through the Juan de Fuca Strait shortly before $14,460 \pm 200{ }^{14} \mathrm{C}$ yr B.P. (Herzer and Bornhold, 1982). The southward Puget lobe advanced to its terminal position in Puget Sound by around $14,150{ }^{14} \mathrm{C}$ yr B.P. (Porter and Swanson, 1998). Ice retreated from its maximum to northern Whidbey Island by $13,650 \pm 350{ }^{14} \mathrm{C}$ yr B.P. (Dethier and others, 1995). Retreating glaciers resulted in a thick sequence of ice-contact, glacial-marine sediment, and early post-glacial sediments (Linden and Schurrer, 1988). These deposits have experienced the effects of a marine transgression followed by regression, resulting in a sea-level several

\footnotetext{
${ }^{1}$ U.S. Geological Survey.

${ }^{2}$ University of Washington, Friday Harbor Labs.

${ }^{3}$ Northern Illinois University.

${ }^{4}$ National Park Service.

${ }^{5}$ National Oceanic and Atmospheric Administration, National Ocean Survey.

${ }^{6}$ Washington Department of Natural Resources, Department of Fish and Wildlife.
} 
tens of meters lower than the present day (Linden and Schurrer, 1988). A second transgression brought sea level to about the present level by around 5,470 $\pm 120{ }^{14} \mathrm{C}$ yr B.P. (Clague and others, 1982) establishing the present oceanographic and geologic environment

Puget Sound is separated into four interconnected basins; Whidbey, Central (Main), Hood Canal, and South (Thomson, 1994). The Whidbey, Central, and Hood Canal basins are the three main branches of the Puget Sound estuary and are separated from the Strait of Juan de Fuca by a double sill at Admiralty Inlet. The Admiralty Inlet map area includes the Inlet and a portion of the Whidbey Basin (fig. 1). The shallower South Basin is separated by a sill at Tacoma Narrows and is highly branched with numerous finger inlets. Flow within Puget Sound is dominated by tidal currents of as much as $1 \mathrm{~m} / \mathrm{s}$ at Admiralty Inlet, reducing to approximately $0.5 \mathrm{~m} / \mathrm{s}$ in the Central Basin (Lavelle and others, 1988). The lack of silt and clay-sized sediments in the Admiralty Inlet map area is likely a result of the strong currents (see Ground-Truth Studies for the Admiralty Inlet Map Area, sheet 3). The subtidal component of flow reaches approximately $0.1 \mathrm{~m} / \mathrm{s}$ and is driven by density gradients arising from the contrast in salty ocean water at the entrance and freshwater inputs from stream flow (Lavelle and others, 1988). The total freshwater input to Puget Sound is approximately $3.4 \times 10^{6} \mathrm{~m}^{3} /$ day, primarily from the Skagit River (Cannon, 1983). The subtidal circulation mostly consists of a two-layered flow in the basins with fresher water exiting at the surface and saltier water entering at depth (Ebbesmeyer and Cannon, 2001). In general, surface waters flow north and deeper waters flow south; variations arise from wind effects that can drive a surface current in the same direction as the wind, and a baroclinic response in the lower layer to about 100-m depth (Matsuura and Cannon, 1997). Oceanographic properties are influenced by temporal forcing parameters such as reduced stream flow during the 2000-01 drought that increased surface salinity and decreased differences between surface and bottom waters (Newton and others, 2003).

On offshore seismic-reflection profiles, Pleistocene strata (excluding latest Pleistocene glacial and post-glacial deposits) form a distinct seismic unit, bounded below by pre-Tertiary or Tertiary basement and above by typically flat-lying latest Pleistocene to Holocene deposits that fill in erosional or depositional relief (Johnson and others, 2001). Cores from central Puget Sound have accumulation rates that range from 85 to $1200 \mathrm{mg} / \mathrm{cm}^{2} / \mathrm{yr}$, or 0.12 to $2.4 \mathrm{~cm} / \mathrm{yr}$; the highest accumulation rates are near the southern end of central Puget Sound (Carpenter and others, 1985). Carpenter and others (1985) unweighted arithmetic mean of accumulation rates for central Puget Sound deeper stations is $480 \pm 340$ ( \pm one standard deviation) $\mathrm{mg} / \mathrm{cm}^{2} / \mathrm{yr}$. Lavelle and others (1985) also found rates as high as 1200 $\mathrm{mg} / \mathrm{cm}^{2} / \mathrm{yr}$ over the past approximately 70 years in cores in the Central Basin off of and north and south of Elliott Bay. Puget Sound basin rates are comparable to rates in midshelf silt deposits on the Washington coast north of the Columbia River (Nittrouer and others, 1979).

The deep subtidal (in other words, below SCUBA depths) habitats of Puget Sound are relatively poorly known. A few subtidal surveys exist for several habitat types from the 1960s and 1970s (reviewed in Dethier, 1990), using grab and box core data. The Dethier (1990) review divides habitat up into Coast and Marine Ecological Classification Standard (CMECS) substrate, water column energy, and depth zones but does not attempt to map these habitats, rather it is an inventory of habitats found in the area and the flora and fauna associated with each habitat.

The approach of the Southern Salish Sea Mapping project is to create highly detailed seafloor maps through collection, integration, interpretation, and visualization of swath sonar data (the undersea equivalent of satellite remote-sensing data in terrestrial mapping), acoustic backscatter, seafloor video, seafloor photography, and bottom-sediment sampling data. This approach is based in part on methods presented and data collection and product needs identified at the Washington State Seafloor Mapping Workshop (Washington State Seafloor Mapping Workshop Steering Committee, 2008), attended by coastal and marine managers and scientists. The map products display seafloor geomorphology and substrate, and identify potential marine benthic habitats. It is emphasized that the more interpretive 
habitat and geology maps rely on the integration of multiple, new high-resolution datasets and that mapping at small scales would not be possible without such data. Oceanographic current and wave data is not included in this analysis, however, the accompanying geographic information system (GIS) data set is designed and intended to be combined with oceanographic and biologic data sets assembled by others in the future and some of the GIS data has already been incorporated in the unpublished Nature Conservancy Benthic Habitats of Puget Sound database.

This publication includes four map sheets, explanatory text, and a descriptive pamphlet. Each map sheet is published as a portable document format (PDF) file. ESRI ${ }^{7}$ ArcGIS compatible geotiffs (for example, bathymetry) and shapefiles (for example video observation points) will be available for download in the data catalog associated with this publication (Cochrane, 2015). An ArcGIS Project File with the symbology used to generate the map sheets is also provided. For those who do not own the full suite of ESRI GIS and mapping software, the data can be read using ESRI ArcReader, a free viewer that is available at http://www.esri.com/software/arcgis/arcreader/index.html.

\footnotetext{
${ }^{7}$ Environmental Systems Research Institute, Inc.
} 


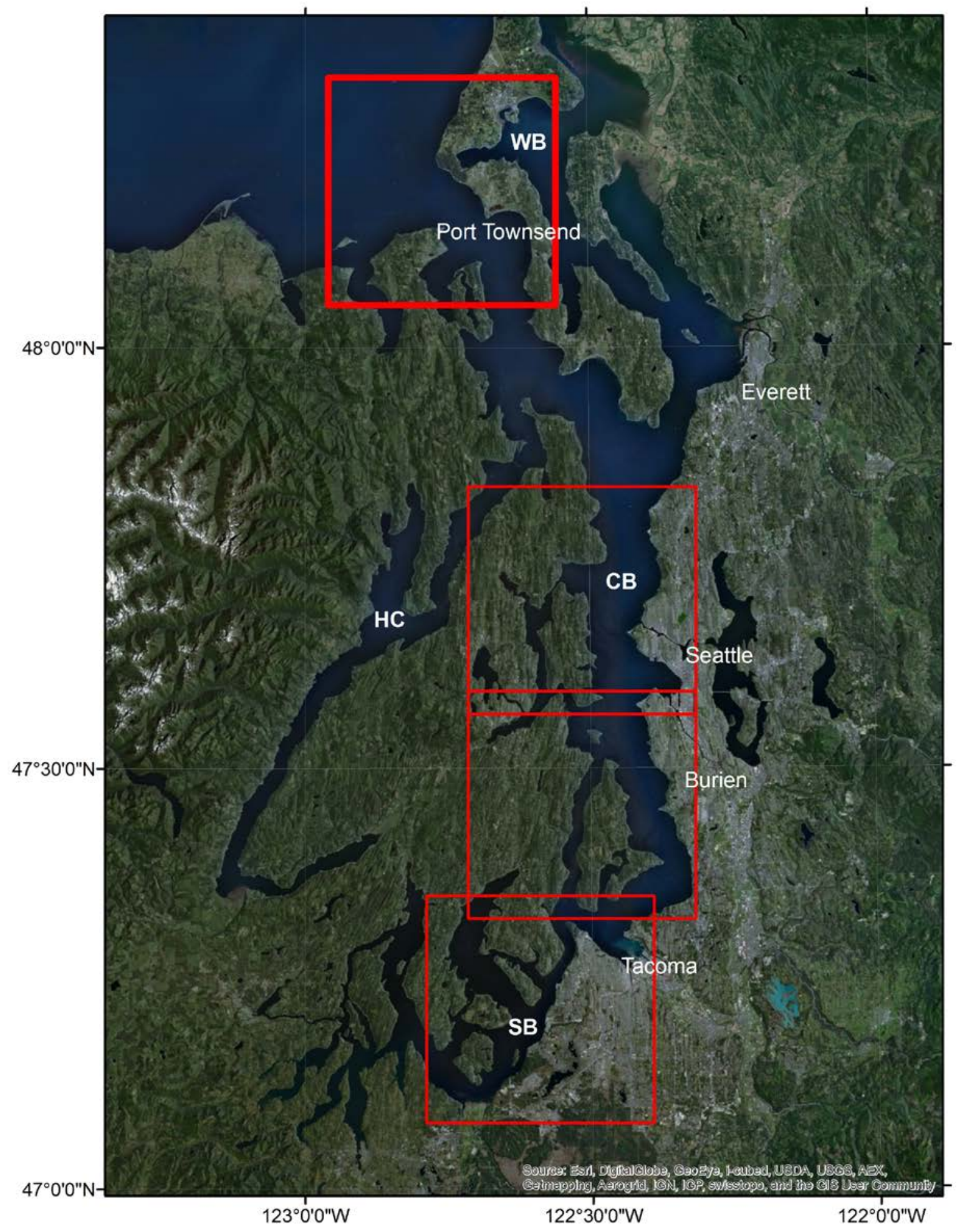

Figure 1. Location of the Southern Salish Sea map areas. The Admiralty Inlet map area is shown in bold. The four Puget Sound basins are the Whidby Basin (WB), Central Basin (CB), Hood Canal Basin (HC) and Southern Basin (SB). 


\section{Bathymetry Map (Sheet 1)}

By Andrew C. Ritchie, Guy R. Cochrane, and Crescent H. Moegling

The colored shaded-relief bathymetry map (sheet 1) of the Admiralty Inlet map area in the southern Salish Sea was generated from topography extracted from a Digital Elevation Model (DEM) by Finlayson (2005) and bathymetry data collected more recently by the National Oceanic and Atmospheric Administration (NOAA; fig. 2). Surveys conducted in the Admiralty Inlet map area by the NOAA Ship Rainier include H11188 (National Oceanic and Atmospheric Administration, 2002), H11040 (National Oceanic and Atmospheric Administration, 2002b), H11039 (National Oceanic and Atmospheric Administration, 2002c), H11038 (National Oceanic and Atmospheric Administration, 2002d), and H11375 (National Oceanic and Atmospheric Administration, 2005). Multibeam sonar data were acquired by the Ranier and its survey launches using Reson 8101, Reson 8125, and Elac 1180 multibeam systems. Sound velocity profiles were measured with SEACAT SBE 19 Plus Profilers. 


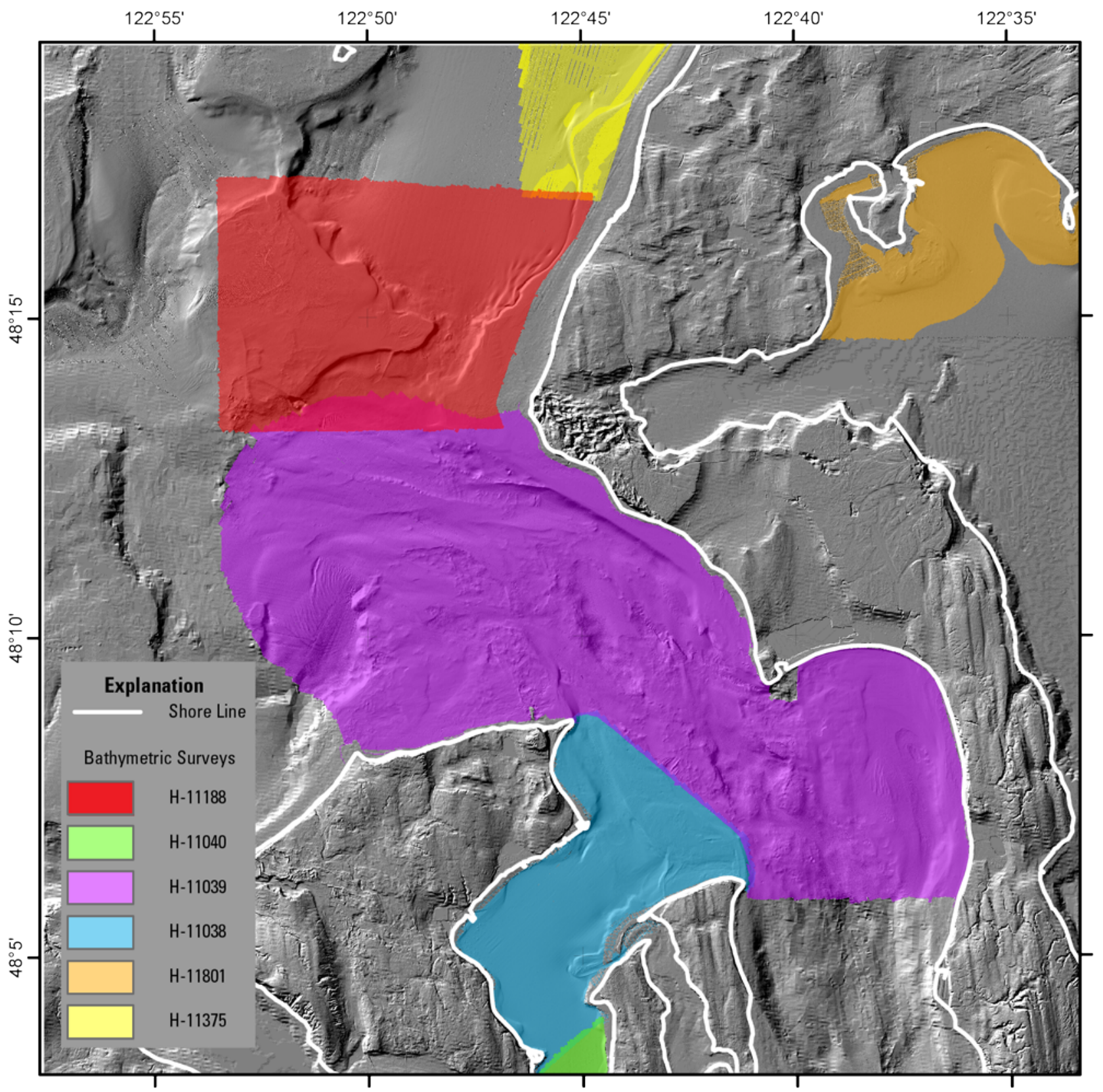

Figure 2. Areas of National Oceanic and Atmospheric Administration surveys used to create map area digital elevation model.

The horizontal datum for Rainier surveys is the North American Datum of 1983 (NAD83). Differential GPS (DGPS) was the sole method of positioning. Differential corrections from U.S. Coast Guard beacons at Whidbey Island (transmitting on $302 \mathrm{kHz}$ ), and Robinson Point (transmitting on 323 $\mathrm{kHz}$ ) were utilized during surveys. The vertical datum for the Rainier surveys is Mean Lower-Low Water (MLLW). The operating National Water Level Observation Network (NWLON) primary tide station at Port Townsend, Alaska (944-4900) served as control for datum determination and as the primary source for water level reducers. 
In addition to Rainier surveys, survey H11801 (National Oceanic and Atmospheric Administration, 2009), was conducted using the Kvichak Defender IV for multibeam sonar and sound velocity data collection in waters deeper than $4 \mathrm{~m}$. Complete multibeam coverage was verified while in the field using a CARIS workstation aboard Kvichak Defender IV, with subsequent verifications performed shore-side on non-survey days. A CODA F-180 motion reference unit was mounted in a water-resistant case to the mid-ships port gunwale immediately adjacent to the Kongsberg EM3002 sidepole mount. The F-180 GPS antennae were mounted in an along-ship orientation with a 2-m-separation between primary and secondary antennae. The $R / V$ Storm was used for gap-fill surveys on January 20 27, 2009, February 3-6, 2009, and February 17-18, 2009. The $R / V$ Storm was configured with a dualhead Reson 7125 multibeam echosounder and tasked with acquisition of least depths on rocky shoals at the approach to Oak Harbor channel, as well as performing gap-fills after conclusion of large boat operations by Kvichak Defender IV. R/V Storm employed Hypack for navigation and raw data acquisition, POS/MV was used for motion and heading, and a Sea-Bird CTD for sound speed profiles.

Once all of the bathymetric-surface models were transformed to a common projection and datum, the files were merged into one overall 2-m-resolution bathymetric-surface model, merged with an onshore DEM from Finlayson (2005), and clipped to the boundary of the map area. Difference calculations of the overlapping bathymetry grids showed that there is good agreement between surveys, even though the surveys were conducted at different times.

An illumination having an azimuth of $315^{\circ}$ and from $45^{\circ}$ above the horizon was then applied to the digital elevation model to create the shaded-relief imagery. A rainbow color ramp was applied to the bathymetry data for sheet 1 , using reds and oranges to represent shallower depths, and blues to represent greatest depths. The colored bathymetry surface was draped over the shaded-relief imagery at 60percent transparency to create a colored shaded-relief map (sheet 1). Bathymetric contours (sheets 1-4) were generated from the surface using ESRI ArcMap. 


\title{
Ground-Truth Studies for the Admiralty Inlet Map Area
}

\author{
By Guy R. Cochrane, Andrew C. Ritchie, Kristine J. Kull, Nadine E. Golden, and Robert E. Pacunski
}

To validate the interpretations of sonar data in order to turn it into geologically and biologically useful information, the U.S. Geological Survey (USGS) towed a camera sled (fig. 3) over specific locations throughout the Admiralty Inlet map area to collect video and photographic data that would ground-truth the seafloor. The ground-truth survey conducted in the Admiralty Inlet map area occurred in 2008 (U.S. Geological Survey, 2008) on the $R / V$ Tombolo in cooperation with the Tombolo Mapping Lab. The camera sled was towed 1-2 $\mathrm{m}$ above the seafloor at speeds of between 1 and 2 nautical miles/hour. The survey for this map area includes approximately $6 \mathrm{hr}$ (9.1 trackline km) of video.

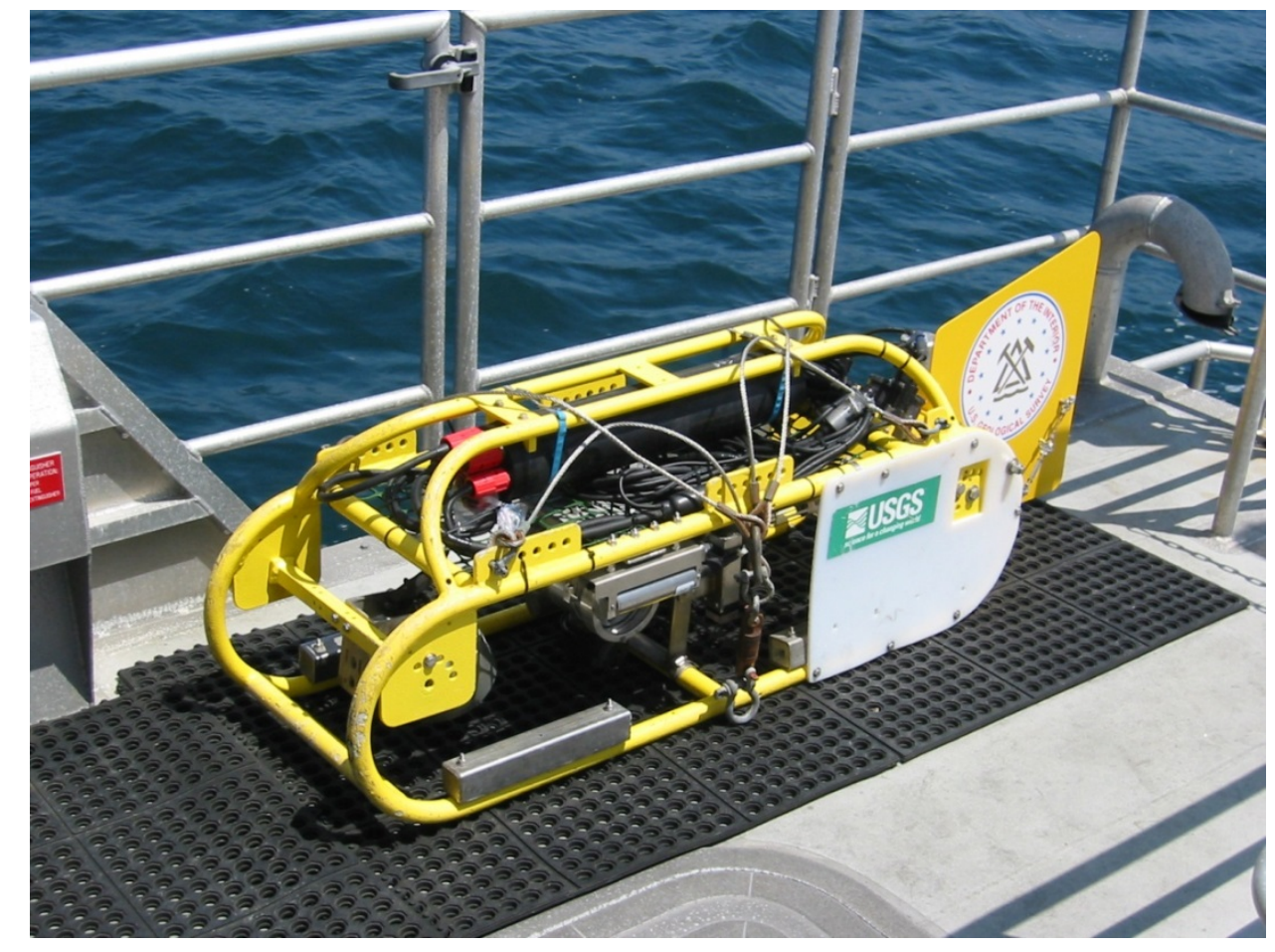

Figure 3. Photograph of one of three different camera sleds used in U.S. Geological Survey ground-truth surveys for the Southern Salish Sea Mapping Project.

The camera-sled tracklines (fig. 4) are subjectively sited in order to visually inspect areas representative of the full range and rugosity in the map area. They were not randomly selected because the number of sites would need to increase beyond the budget of the project in order to ensure adequate sampling of the full range of bottom types in the area. In addition, the tether length of the $R / V$ Tombolo camera system restricted the ground-truth survey to depths less than $30 \mathrm{~m}$. Interpretation of the substrate and geomorphology (see CMECS Geoform and Substrate Maps) of deeper portions of the map area are based on grab samples collected on the ground-truth survey (fig. 4), previously published information, and geologic reasoning. The video is relayed in real time to the research vessel, where scientists record both the geologic and biologic characteristics of the seafloor. While the camera is deployed, several different observations are recorded for a 10-s period once every minute, using the protocol of Anderson and others (2007). Observations of primary substrate, secondary substrate, slope, abiotic complexity, biotic complexity, and biotic cover are mandatory. Observations of key geologic features and the 
presence of key species also are made. On USGS field activity T-01-08-PS (U.S. Geological Survey, 2008) 190 observations were recorded in the map area and 27 grab samples were obtained (fig. 4).

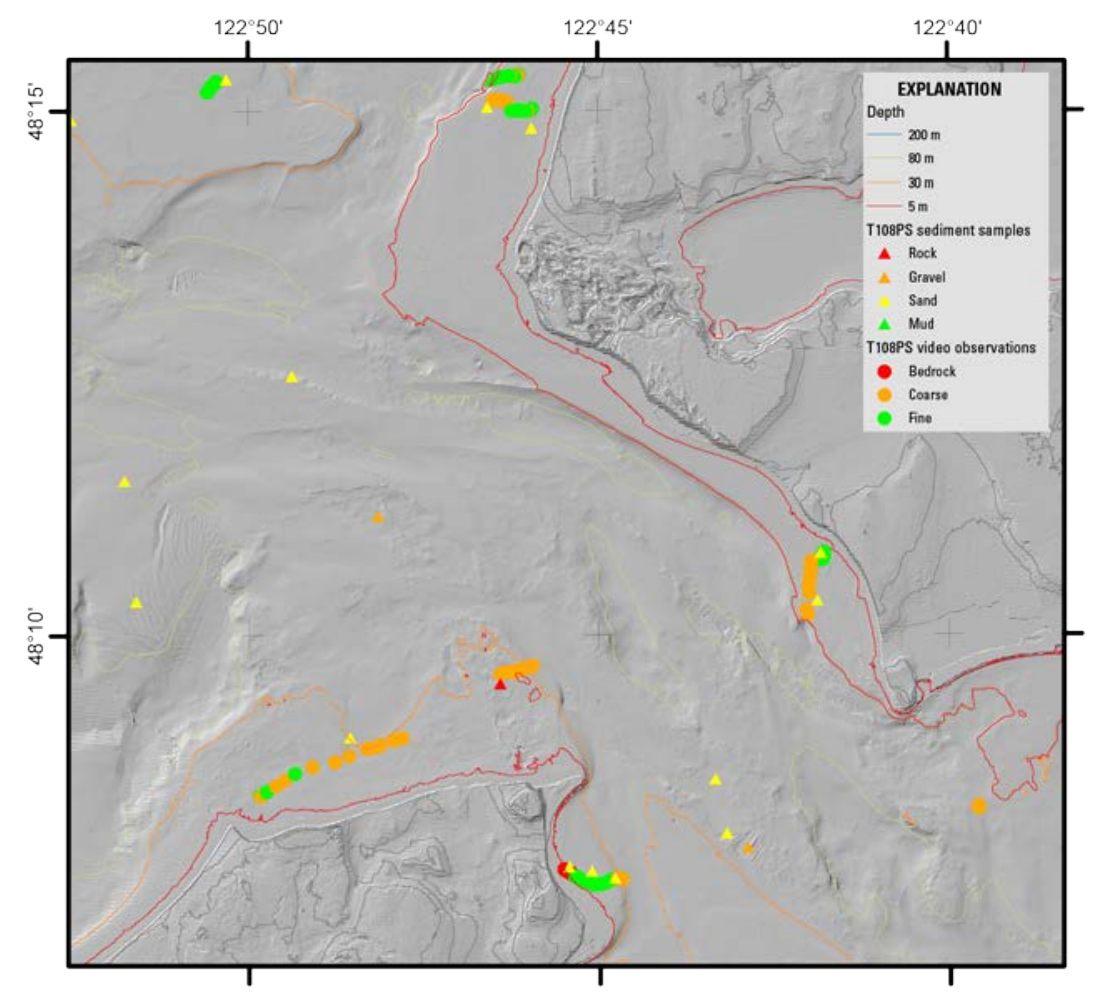

Figure 4. Video and sampling sites in the Admiralty Inlet map area.

Primary and secondary substrates constitute greater than 50 and 20 percent of the seafloor, respectively, during an observation (Tissot and others, 2006). The classifications are based on the Wentworth scale, except that the granule and pebble sizes have been grouped together into a class called "gravel," and the clay and silt sizes have been grouped together into a class called "mud." Benthichabitat complexity, which is divided into abiotic (geologic) and biotic (biologic) components, refers to the visual classification of local geologic features and biota that can potentially provide refuge for both juvenile and adult forms of various species (Tissot and others, 2006).

In the Admiralty Inlet map area, the surface is predominantly covered by sediment with a grain size distributed normally around the sand-size class (fig. 5). There is one small area of rock noted in the observations as a glacial-till deposit. 


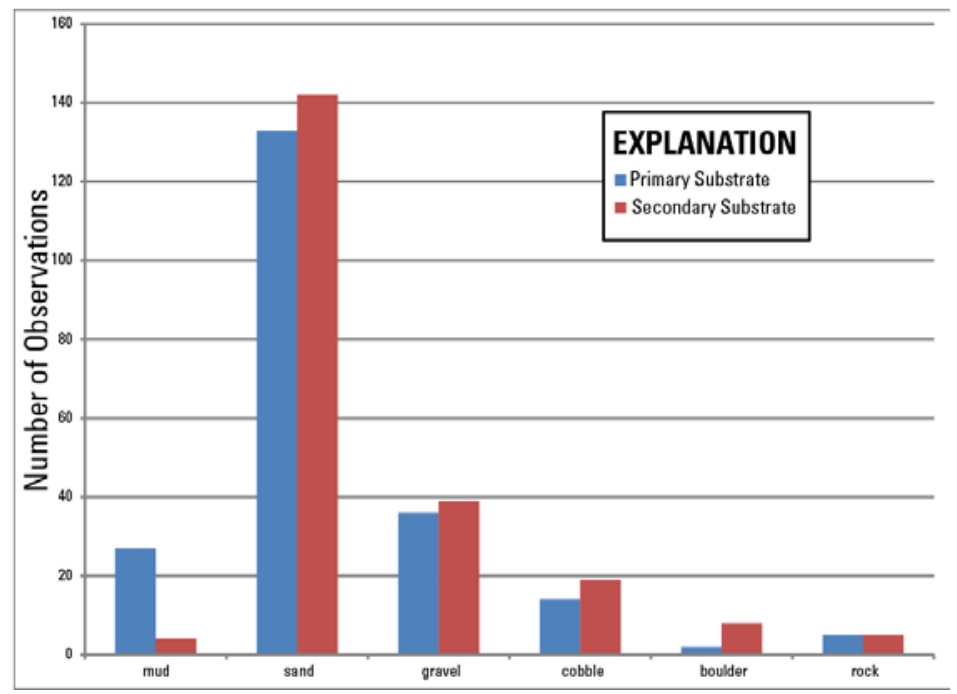

Figure 5. Graph showing distribution of primary and secondary substrate determined from video observations and grab samples collected during the ground-truth survey in the Admiralty Inlet map area. 


\title{
CMECS Geoform and Substrate Maps (Sheet 2 and 3)
}

\author{
By Timothy O. Hodson, Guy R. Cochrane, Andrew C. Ritchie, and Crescent H. Moegling
}

Given the variable bathymetric resolution, the complex geologic history of the region, and the lack of acoustic backscatter data, automated and semi-automated schemes of classifying seafloor substrate and geoform were deemed to have very low accuracy. Instead, classification of these properties was performed manually following the Coastal and Marine Ecological Classification Standard (CMECS; Madden and others, 2009). The CMECS geoform map (sheet 2) and the CMECS substrate map (sheet 3) display information also available in a GIS polygon shapefile (Cochrane, 2015).

Geoforms describe the physical structure of the seafloor and can represent a control on processes such as (1) water exchange rates and water turnover times; (2) hydrologic and energy cycling; (3) shelter and exposure to energy inputs; and (4) migration and spawning (Madden and others, 2009). In general, the specificity of our CMECS geoform interpretations reflects the resolution of the underlying NOAA bathymetry. Where there was sufficient resolution to attribute a particular genetic process to a geoform, we ascribed an appropriately specific geoform type. Where bathymetric resolution was low and the genetic interpretation equivocal, our geoform classifications were more generic. Seafloor geoforms were classified based on their physical attributes as observed in the NOAA bathmetric surveys and USGS seismic reflection profiles (U.S. Geological Survey, 1995; 1997) in combination with knowledge of common glacial and estuarine processes and interpretations from the regional geologic literature (for example, Hewitt and others, 2001; Mosher and others, 2004).

The CMECS substrate component is intended to characterize the most ecologically significant geological features of the substrate surface according to composition and particle size (Madden and others, 2009). Seafloor substrates were mapped based on USGS seafloor video transects (see GroundTruth Studies for the Admiralty Inlet Map Area), NOS seabed descriptions, known associations between specific geoforms and substrates, and two derivative bathymetric properties - seafloor rugosity (a dimensionless measure of seafloor roughness) and slope. In general, a higher rugosity is characteristic of rough substrates such as rocky areas, whereas lower rugosity is characteristic of flat, less complex, softbottom substrates. Seafloor slope can give an indication of substrate due to the proportionality between angle of repose (the steepest stable slope angle a particular loose material) and sediment's shear strength. Therefore, only well consolidated material, such as glacial sediments or bedrock are stable on very steep slopes, and very weak sediments, such as pelagic muds or re-deposited gravity flows, can only accumulate on areas of low slope.

Particular geoforms also form in response to specific seafloor processes that are known to influence substrate. In some cases, geoforms can be indicative of specific substrates, such as the association between deltas and the deposition of sandy, fluvially sourced material or between basin floors and pelagic deposition dominated by finer grained sands and muds. Other geoforms provide only relative information about potential substrates. For example, forms indicative of scouring processes indicate winnowing, and therefore a general coarsening relative to the surrounding seafloor. The structure of geoforms can also indicate or directly influence local current patterns that affect substrate. Structures causing, or indicative of, convergent flow in a water body are associated with higher local current speeds, and therefore coarser substrates. Whereas, structures that produce, or are the product of divergent flow, may be associated with a fining in substrate due to the drop in transport capacity and current velocity.

Similarly to our geoform map interpretations, the specificity in our substrate interpretation reflects the underlying data coverage and quality. Areas near USGS seafloor video transects, within the primary study region (colored areas in fig. 2) were classified with more specificity, down to substrate group or substrate subgroup, depending on proximity to ground-truth surveyed transects and the local 
heterogeneity of the seafloor. Our classification of substrates in areas outside of the primary study region was based primarily upon geomorphological interpretations drawn form historical NOS surveys and historical NOS seabed descriptions. Consequently, these interpretations are less specific; substrate classifications in these areas are typically limited to the substrate class or substrate subclass. 


\title{
Biotopes (Sheet 4)
}

\author{
By Megan N. Dethier, Guy R. Cochrane, and Kristine J. Kull
}

The distributions of benthic marine organisms tend to be closely tied to habitat types that can be defined by a small number of key physical and chemical parameters such as substrate type, energy level, salinity, and depth (for example, Dethier, 1992; Madden and others, 2009; Barrio Frojan, 2012). Under ideal circumstances, this means that gathering detailed information on habitat characteristics allows us to predict the biota expected there. Quantifying and testing species-habitat relationships is relatively straightforward in accessible areas such as the intertidal zone (for example, Schoch and Dethier, 1996), but much more complex in subtidal environments where both precise habitat descriptions and biotic surveys are logistically difficult.

The increasing need to understand habitat requirements of endangered or commercially important fish species has contributed to the rapid development of techniques for underwater mapping of physical and biological elements (extensive literature reviewed in Brown and others, 2011). Physical/environmental habitat mapping methods include single beam (for example, Stolt and others, 2011), dual frequency (for example, Freitas and others, 2011), and multibeam (for example, Young and others, 2010) echo sounders, with a rapid evolution of sophistication in imaging and mapping of seafloor habitats. Oceanographic data (temperature, salinity, etc.) are often collected simultaneously. Biological surveys of these same habitats may use acoustic data (for features such as eelgrass beds that have a recognizable acoustic signal), benthic grab samples, trawls, towed videos, and submersibles. Analytical methods used to seek patterns of biological assemblages with mapped physical features include generalized linear models, multivariate analyses (clustering and linkages), and GIS database layer comparisons. Brown and others (2011) review many of the methods of both collecting and analyzing data, with the ultimate goal usually being to create maps of the predicted distributions of target species, whole communities, or abiotic surrogates for particular species.

Habitat classification schemes are generally part of this process. Classifications are often hierarchical, with higher levels composed of easily defined abiotic characteristics (oceanographic and/or geomorphic), and lower levels often defining biotopes, "a combination of an abiotic habitat and its associated community of species" (Connor and others, 2004). In the U.S., attempts to create a standardized classification system, led by NOAA, have produced several versions of the Coastal and Marine Ecological Classification Standard (CMECS; Madden and others 2009) available at http://www.csc.noaa.gov/benthic/cmecs/. The system was designed to have a standardized but flexible lexicon that could provide consistency in format and language among projects and regions. The system incorporates classification rationale from Cowardin and others (1979) and from Greene and others (1999). To date it has only been tested as a mapping system in a few discrete locations (for example, Keefer and others, 2007; Trusel and others, 2010). CMECS uses oceanographic, physiographic, and biological criteria as a basis for defining classes, and is to some extent scale-independent (Dethier and Harper, 2012).

\section{Methods}

The Video Annotation and Reference System (VARS) Annotation software created by the Monterey Bay Aquarium Research Institute ( MBARI) was used to play and annotate video footage that had been captured either by Remotely Operated Vehicle ( ROV) (aboard $R / V$ Tombolo and $R / V$ Molluscan) or camera sled (aboard $R / V$ Karluk). VARS was programmed with a customized set of 'organism buttons' for recording observed biota to be custom built from a library of biota in the VARS 
software Knowledge Base lists (table 1). All video analysis was done by one observer (Kull) for consistency.

Once a minute, the name (button) of identified organisms was clicked/annotated in VARS. Anytime between the start (m:00) and end (m:59) of a minute, the observer clicked a particular name button only once, regardless of how many times that organism was observed during the minute.

Some of the ROV footage ( $R / V$ Tombolo, $R / V$ Molluscan) was slow enough that it was viewed in normal time, but almost all of the camera sled footage ( $R / V$ Karluk) had to be viewed at 40 percent speed. That speed was settled upon because anything slower caused analysis to take too long, and anything faster did not provide the additional observation time necessary. Often, pausing or slowshuttling the footage resulted in a blurred image that did not help with identification. In many instances identifications were made by making educated guesses, based on previous observations made at slower tow speeds or better video resolution, and (or) the context/habitat of the video being watched. The observer strove to keep those procedures consistent and yet not assume organisms were something seen previously. The set of buttons used and the organisms they represent are listed in table 1 .

Physical data were binned into 1-minute intervals and compiled and matched with time intervals for which the organisms were recorded from the video. Some physical such as depth, slope, Vector Ruggedness Measure (VRM), Bathymetric Position Index (BPI), others are qualitative (for example substrate data were binned into 6 primary and 6 secondary categories from mud to bedrock). Excel files with the physical data and the biotic data (in presence/absence form) were imported into PRIMER 6 statistical software to the analysis of multivariate data and analyzed with a variety of multivariate routines. Before analysis, the physical data were 'normalized' (for each variable, the program makes the mean 0 and the standard deviation 1) so that all were on the same scale and their relative importance in driving patterns could be compared. Depth was binned into five categories: Shallow (0-14 m), ModShallow (15-24 m), Mod-Deep (25-50 m), Deep (50-149 m), and Very Deep (>150 m) based on Dethier (1990) classes.

\section{Results}

Tracklines for the transects surveyed with video in the Admiralty Inlet map area are shown in figure 4. Depths and substrates in the video from this map area differed from those to the south (fig. 1); the Admiralty Inlet map area included no Very Deep (>150m) areas, and far more Shallow areas (fig. 6). This is a function of the depth limitations of the survey operation (described in the Introduction). Cobble substrates (especially in the Deep zone) were far more common than in map areas to the south, possibly due to removal of fine-grained sediment by currents in the area surveyed. In this map area boulders were restricted to the Deep and Moderately-Deep depth zones and no bedrock was observed. 


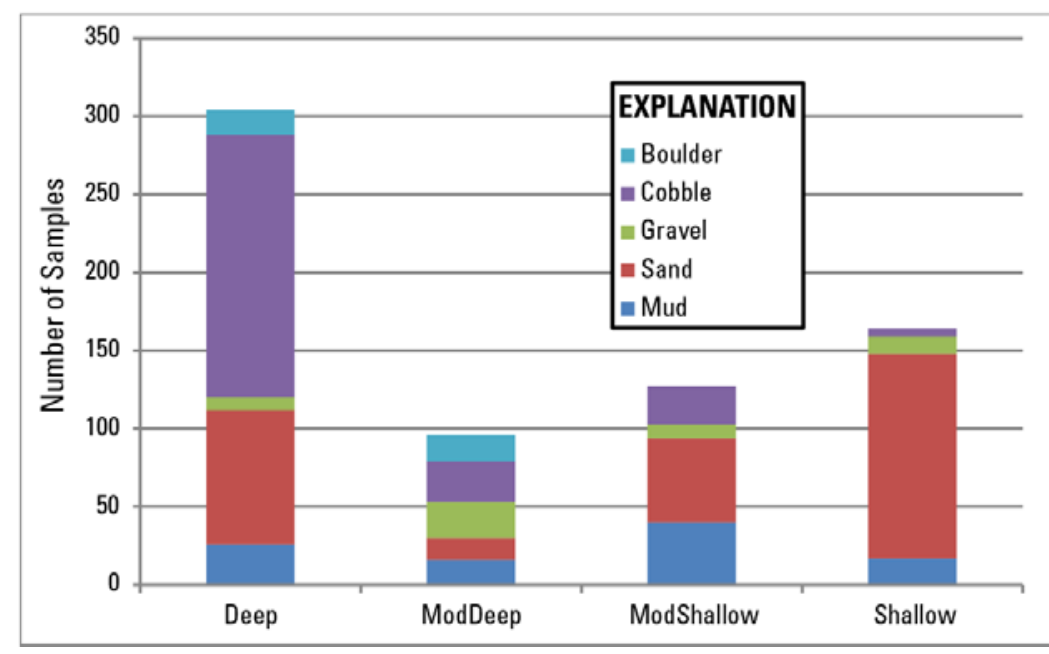

Figure 6. Numbers of samples in each depth and primary substrate type in Admiralty Inlet map area. Depth classes shown based on Dethier (1990); Deep (50-149 m), ModDeep (moderate-deep) (25-50 m), ModShallow (moderate-shallow) (15-24 m), Shallow (0-14 m).

The full database for the Admiralty Inlet map area contained 691 sample units. Drift algae, or algae that have become detached from their substrate and are being carried elsewhere by currents, were present in a large proportion of samples (table 1). Since their presence is not representative of the biotic community living in an area (except in terms of providing temporary habitat or nutrition) and because their high frequency provided misleading similarity among many samples, we removed them from analysis of overall biotic assemblages. In addition, because community analyses are virtually meaningless with very depauperate communities, the 295 samples with only 1-3 taxa were omitted for multivariate analyses, leaving 396 samples with 4-13 taxa per sample. Taxa richness for the full database is shown in figure 7. The overall average number of taxa per sample was 4.7 (similar to areas to the south).

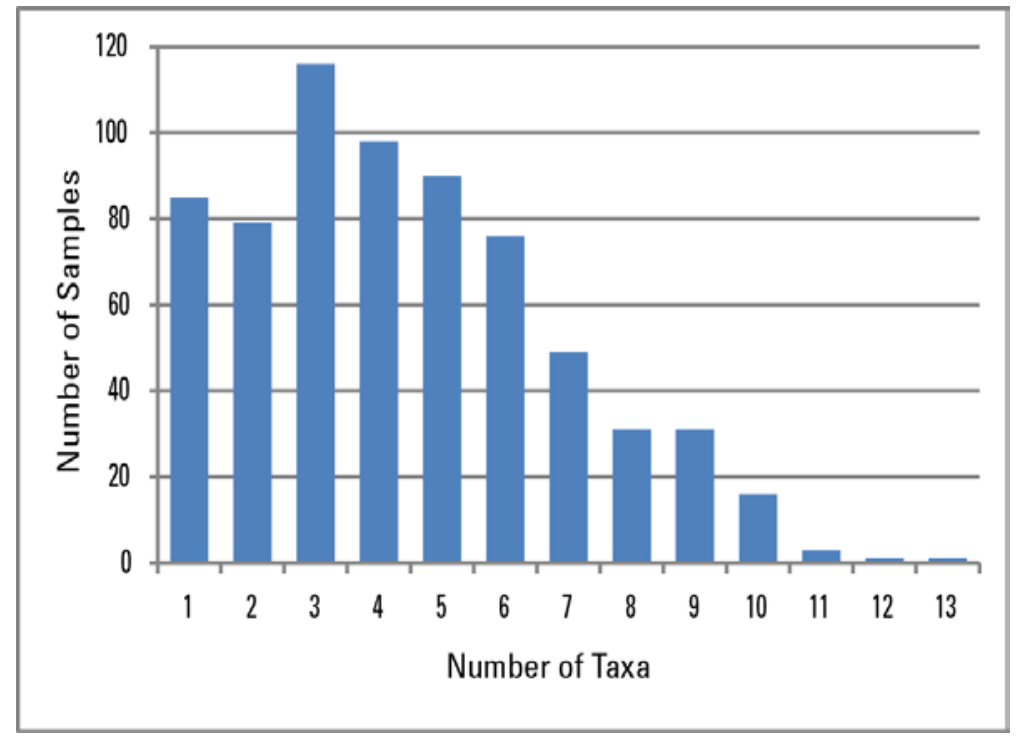

Figure 7. Taxa richness for all 691 Admiralty Inlet map area sample units. 
Distribution of the samples among depths and substrate types was different for the richer dataset than for the full dataset (fig. 8). A higher proportion of richer samples was found in the deeper zones and in coarser substrates, especially cobble. Samples whose primary substrate was sand had a relatively large proportion of low-richness samples.

Multivariate analyses were run on the 396 samples with 4-13 taxa per sample. In non-metric multidimensional scaling (MDS) plots, each point represents the biotic assemblage in one sample. Points closer together have more similar assemblages, in other words, more taxa in common (all presence/absence data). ANOSIM (Analysis of Similarity) tests were run on the variation of the biotic assemblages with factors such as depth, producing Global R values; if each group (for example, depth) had distinctly different biota, the $\mathrm{R}$ would be close to 1.0, and it would be possible to readily draw a circle around each set of depth-points without these circles overlapping. Another way to examine the biotic data is to have the software cluster the samples by their biotic similarity, in other words, to create groups that are biotically different at a particular statistical level, then overlay such clustering results on an MDS plot. The program that calculates these clusters (SIMPROF) can show group structure at any significance level. More relaxed significance levels (for example, 5 percent) generate very high numbers of “different” groups, given the very large number of samples. More strict significance levels (for example, 0.5 percent) led to combining many samples into relatively few groups, losing our ability to differentiate real assemblages. These cluster groups vary highly in their dispersion, or how spread out the points are in the plot, which is an indicator of how biotically different the samples are. Physical data were similarly clustered. This degree-of-dispersion can also be seen in the metrics of average similarity (for example, table 1), which (in groups of at least 5 samples) ranges from a low of 27 percent similarity (group k) to a high of 71 percent (group c). 


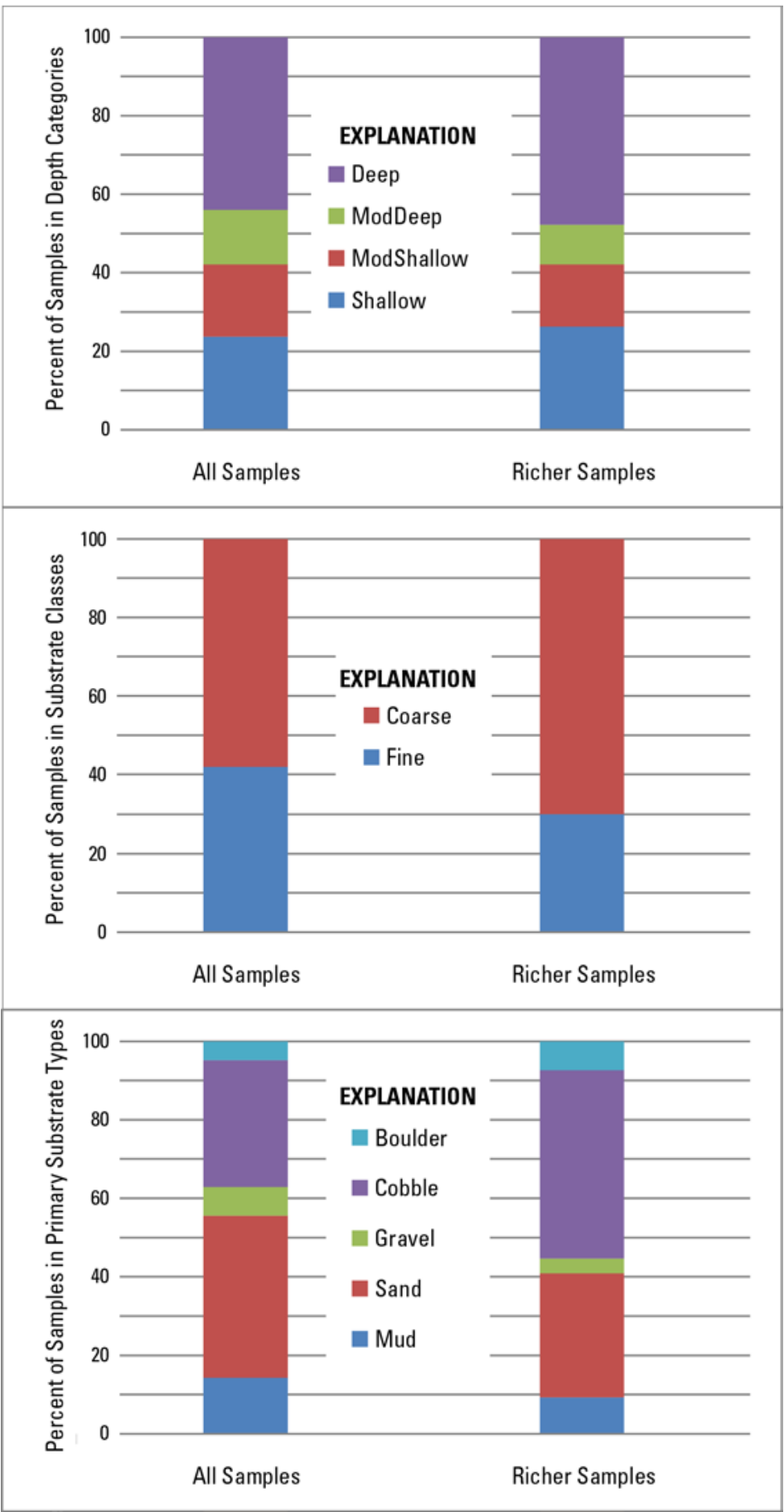

Figure 8. Percent of samples in different depths and substrates in the complete Admiralty Inlet map area dataset (691 samples) and the relatively taxa-rich Admiralty Inlet map area subset (396 samples). 
Overall frequencies of organisms found in the Admiralty Inlet map area are shown in table 1. Drift algae were much less common in areas to the south than in the Admiralty Inlet map area, and relatively more of these observations were in the shallower depths. Some taxa were much more common than in the south; these differences are even more striking than suggested by the number of observations shown in table 1, because the Admiralty Inlet map area had only about half as many samples as areas to the south. Taxa notably more common in the Admiralty Inlet map area included barnacles, all types of algae (green, brown, red, and Laminarians), scallops, and urchins. Taxa notably less common in the Admiralty Inlet map area were cerianthid anemones, ratfish, the seastar Mediaster, the anemone Metridium, and flatfish and rockfish. Some of these organisms were characteristic of the Very Deep samples in the south (for example, cerianthids, Mediaster) and with no samples at this depth in the Admiralty Inlet map area, it is not surprising that they were seen less often.

Table 1. Taxa found in the Admiralty Inlet map area (out of 691 samples) and their frequencies of observation; $\mathrm{SM}$, number of sample-minutes.

\begin{tabular}{|c|c|c|c|}
\hline Code & SM & Description/Common names & Higher Taxon \\
\hline Actiniaria & 121 & All solitary anemones that are not tube anemones & Cnidaria \\
\hline Ascidiacea & 6 & Any species of tunicate & Urochordata \\
\hline Asteriidae & 7 & Mottled, rainbow, black sea stars & Echinodermata \\
\hline Asteroidea & 34 & Other sea stars (bat, slime, sand, leather) & Echinodermata \\
\hline Balanophyl & 15 & Cup corals & Cnidaria \\
\hline Balanus & 203 & Any barnacle species & Arthropoda \\
\hline Bivalvia & 23 & Any bivalve species not scallops, probably mostly mussels & Mollusca \\
\hline bony_fish & 62 & $\begin{array}{l}\text { Any bony fish not otherwise coded; might include some early } \\
\text { Stichaeid observations }\end{array}$ & Chordata \\
\hline Brachiopod & 0 & Brachiopoda & Brachiopoda \\
\hline Bryozoa & 153 & Any Bryozoan, epilithic or epiphytic & Bryozoa \\
\hline Cancer & 19 & All crabs in the Cancer genus & Arthropoda \\
\hline Caridea & 73 & Any shrimp & Arthropoda \\
\hline Cerianthid & 11 & Any burrowing anemone & Cnidaria \\
\hline Chlorophyc & 106 & Any green algae & Algae \\
\hline Cottidae & 13 & Any sculpins & Chordata \\
\hline driftweed & 223 & Any unattached kelp or other algae & Drift \\
\hline eggcase & 15 & Any egg case including gastropod, shark or ray & Misc \\
\hline encrusting & 59 & Any encrusting invertebrate or corallines & Misc \\
\hline Fucus & 0 & Rockweed Fucus & Algae \\
\hline Gadiformes & 4 & Any cod or pollock species & Chordata \\
\hline Gastropoda & 3 & Any gastropod other than nudibranchs & Mollusca \\
\hline Henricia & 148 & Blood star & Echinodermata \\
\hline Hexagrammo & 1 & Greenling and lingcod & Chordata \\
\hline Holothuroi & 67 & $\begin{array}{l}\text { Any species of surface-dwelling cucumber other than } \\
\text { Parastichopus }\end{array}$ & Echinodermata \\
\hline Hydroida & 362 & Any species of hydroid & Cnidaria \\
\hline Hydrolagus & 25 & Ratfish & Chordata \\
\hline Laminarial & 185 & Any kelp species (attached) & Algae \\
\hline
\end{tabular}




\begin{tabular}{|c|c|c|c|}
\hline Code & SM & Description/Common names & Higher Taxon \\
\hline Majidae & 7 & Any spider crab (kelps and decorators) & Arthropoda \\
\hline Mediaster & 5 & Red deep sea star & Echinodermata \\
\hline Metridium & 22 & Metridium anemones & Cnidaria \\
\hline Nudibranch & 1 & Any nudibranch & Mollusca \\
\hline Octopus & 0 & Any octopus & Mollusca \\
\hline Ophiurida & 4 & Any brittle star & Echinodermata \\
\hline Paguroidea & 11 & Any hermit crab & Arthropoda \\
\hline Parasticho & 34 & Giant sea cucumber & Echinodermata \\
\hline Pectinidae & 88 & Rock and swimming scallops & Mollusca \\
\hline Phaeophyco & 126 & Any brown algae & Algae \\
\hline physical_o & 5 & Physical object (eg bottle or tire) & Misc \\
\hline Pisaster & 11 & Any Pisaster & Echinodermata \\
\hline Pleuronect & 14 & Any flatfish & Chordata \\
\hline Porifera & 147 & Any sponge & Porifera \\
\hline Ptilosarcus & 39 & Orange sea pen & Cnidaria \\
\hline Pycnopodia & 75 & Sunflower star & Echinodermata \\
\hline Rajiformes & 1 & Skates and rays & Chordata \\
\hline Rhodophyco & 257 & Any red algae & Algae \\
\hline Sebastes & 0 & Any rockfish & Chordata \\
\hline Solaster & 6 & Any sunstar & Echinodermata \\
\hline Squalomorp & 0 & Dogfish & Chordata \\
\hline Stichaeida & 11 & Any prickleback, warbonnet & Chordata \\
\hline Strongyl_1 & 136 & Green sea urchins (and white) & Echinodermata \\
\hline Strongyloc & 17 & Red sea urchin & Echinodermata \\
\hline Subsellifl & 5 & Any sea whip & Cnidaria \\
\hline tubeworm & 180 & Colonial and solitary tube worms & Annelida \\
\hline Zoarcidae & 31 & Any eelpout & Chordata \\
\hline Zostera_ma & 33 & Eelgrass & Vascular Plant \\
\hline
\end{tabular}

Some of these groups identified in the clustering routine (fig. 9) are very tight (for example, group $\mathrm{j}$, with very similar assemblages among the samples). This group was characterized by barnacles, tubeworms, and hydroids, and all of the samples were in deep or moderately deep water with coarse substrates (table 2). Group c also showed rather tightly clustered samples, in this case with each of its nine samples containing bivalves (probably mussels), red algae, and eelpouts, and with the physical conditions characterized by fine substrates in moderately shallow water. In contrast, samples in group $\mathrm{k}$ were widely scattered, containing sunflower stars and brown algae (which could have been drift algae in some cases), and with no consistency in depth or substrate types.

MDS plots for taxa-rich samples from the Admiralty Inlet map area biological dataset (fig. 10) show some separation of biotic communities with certain habitat parameters. The ANOSIM test on the variation for primary substrate type was significant $(p=0.001)$, and the $R$ value was quite high $(0.516)$. The biota also cluster quite strongly with depth $(\mathrm{R}=0.608)$, with the Deep samples most clearly separate. The eight possible combinations of depth and substrate subclass (coarse vs. fine) seen in the Admiralty Inlet map area were also examined. While the number of categories makes these patterns difficult to distinguish, the combination of depth and primary substrate had the strongest statistical separation among groups $(\mathrm{R}=0.637)$. All pairwise comparisons of this combination are different except for ModShallow-Coarse and ModDeep-Coarse. 


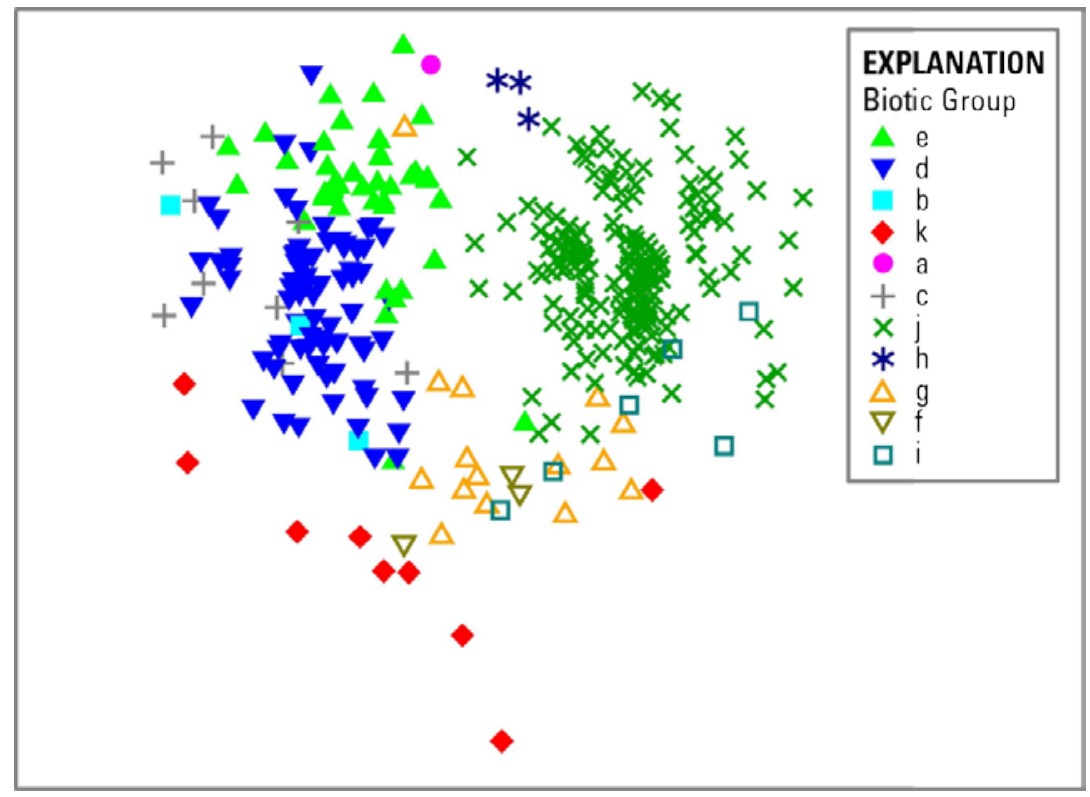

Figure 9. Admiralty Inlet map area biota with samples coded by biotic communities identified in the clustering routine (at the $p=0.01$ level) described in table 2 . 

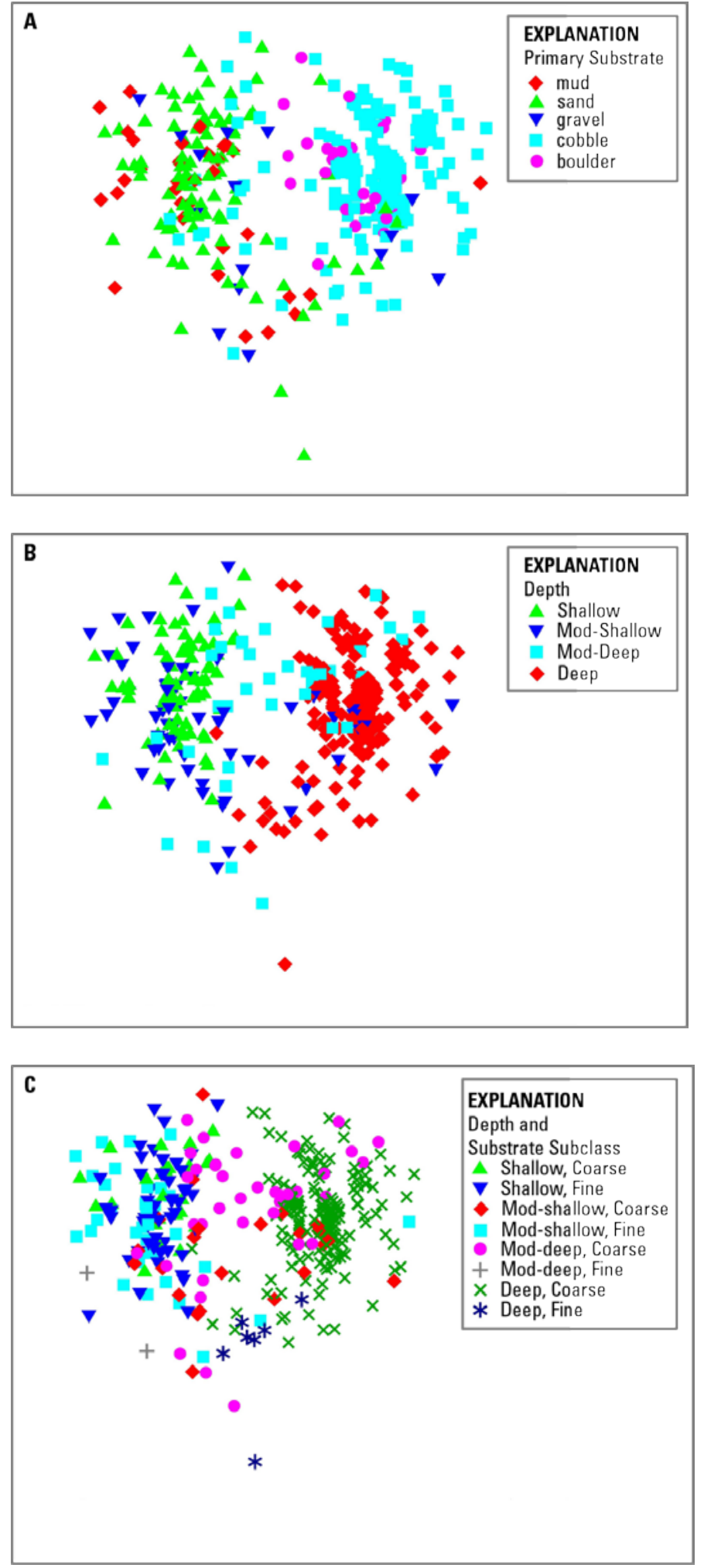

Figure 10. Multidimensional scaling plots of Admiralty Inlet map area biotic communities for $A$, primary substrate; $B$, depth; and $C$, depth and CMECS substrate subclass combined. 
Table 2. Results of SIMPER test for biotic assemblage similarities. $N$ values are numbers of samples in each group. Groups are illustrated in Figure 9. "Avg. Abund" indicates the average among the samples within the group of records of taxa present (1) and absent (0). Taxa contributing at least 9 percent to within-group similarity are listed for each group. Physical variables are listed only when there was moderate within-group consistency. 


\begin{tabular}{|c|c|c|c|c|c|c|c|c|}
\hline Group & $\mathrm{N}$ & Avq Sim. & Mean Richness & Characteristic Taxa & Avg. Abund & Contrb \% & Depth & Substrate \\
\hline
\end{tabular}

b

3

53.7

5

Pycnopodia

Rhodophyco

Chlorophyc

Hydroida

71.3

5.3

Bivalvia

Rhodophyco

Zoarcidae

Chlorophyc

d

107

59.0

4.9

Hydroida

Laminarial

Rhodophyco

Phaeophyco

Chlorophyc

e

45

56.5

5.1

Rhodophyco

Hydroida

encrusting

Laminarial
Only 1 sample in group

1

37.47

1

37.47

0.67

13.78

0.67

11.28

1

26.69

All ModShall

Fine

26.69

1

1

26.69

0.67

10.77

0.81

22.92

Shallow+Mod

Fine

0.8

22.52

0.76

19.82

0.69

16.66

0.59

11.75

30.54

All except Deep

21.57

0.8

21.57

0.64

13.97 
5.5

Hydroida

0.73

21.63

Caridea

Pectinidae

0.6

12.97

h

3

61.1

4.3

Balanus

Rhodophyco

1

37.88

Porifera

0.67

12.12

Pycnopodia

0.67

12.12

i

6

$63.8 \quad 6.5$

Hydrolagus

Ptilosarcu

Balanus

Hydroida

j

195

54.7

7

Balanus

0.89

20.73

Deep and ModDeep

Coarse

tubeworm

0.85

18.88

Hydroida

0.71

12.34

red urchins

0.66

11.07 
Henricia

27.2

4.9

\author{
Phaeophyco \\ Pycnopodia
}

0.78

0.44
43.7

12.93

Very few fishes were found in the Admiralty Inlet map area. The substrate type and depth distributions of four relatively common individual taxa of the Admiralty Inlet map area were examined in detail (fig. 11). Deep areas had relatively frequent occurrences of all of these taxa, and for scallops (Pectinidae) this pattern was particularly striking. Three taxa showed very little pattern with substrate type (there were no bedrock observations in the Admiralty Inlet map area biological analysis dataset), but shrimp showed a clear pattern of greater frequency in fine substrate types.
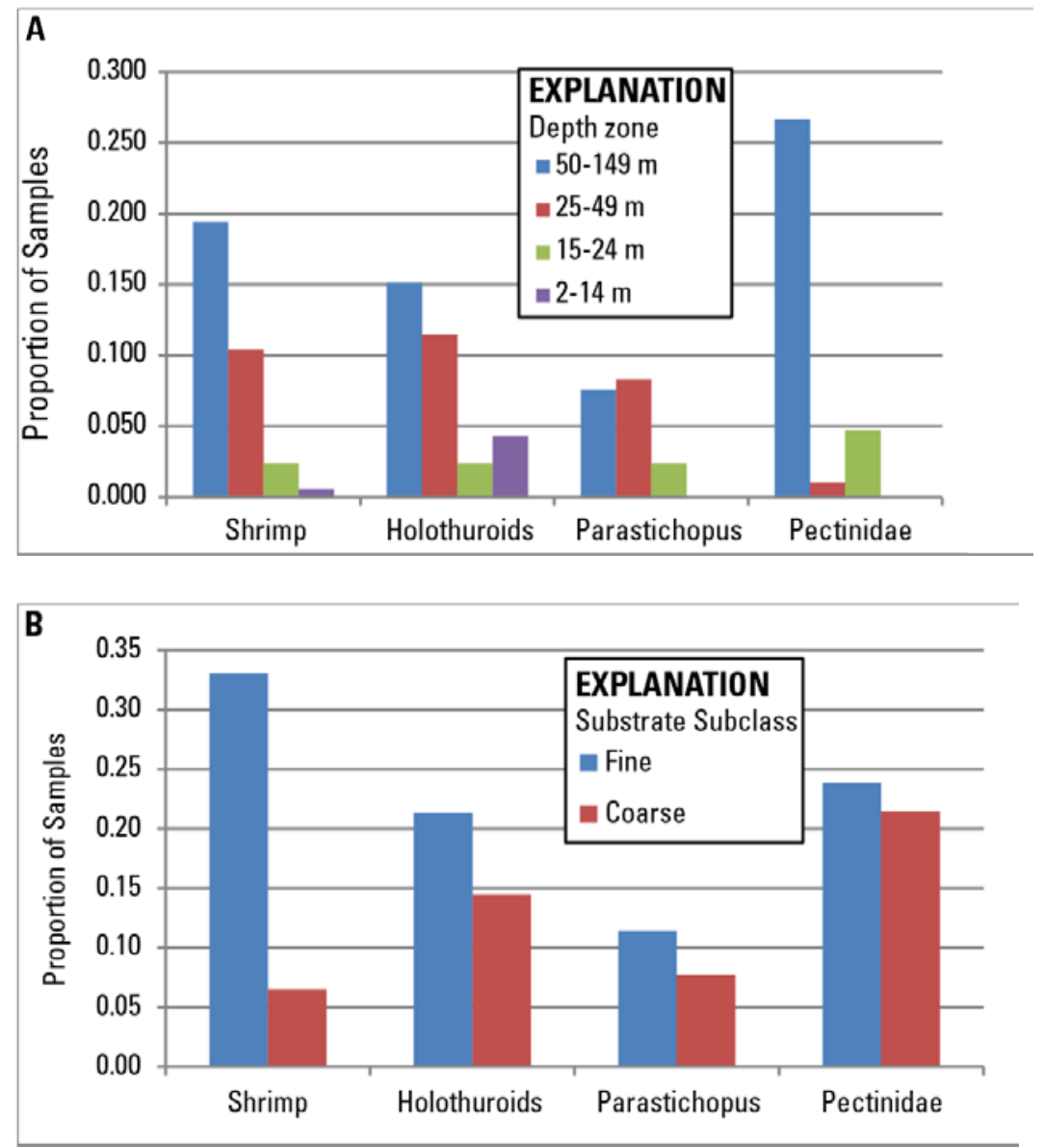

Figure 11. Proportion of total samples containing four key taxa by $A$, depth or $B, C M E C S$ substrate subclass. 'Holothuroids' include species other than Parastichopus. 
The 396 biotically rich samples were analyzed for six physical variables including depth; primary and secondary grain size (Tissot, 2006); Bathymetric Position Index (BPI) and Vector Ruggedness Measure (VRM) from the Benthic Terrain Modeler (National Oceanic and Atmospheric AdministrationNOAA, 2010); and slope. MDS plots showed there to be 5 outliers, which were removed and the data re-analyzed; the outliers had extremely high slope, VRM, and (or) BPI values. Figure 12 shows the draftsman plot for the remaining 391 samples, and table 3 gives the correlations among the variables. Primary and secondary grain size classes were positively correlated (table 3), and grain sizes and depths were negatively correlated; shallower depths had finer substrates (although most substrate types were found at a range of depths).

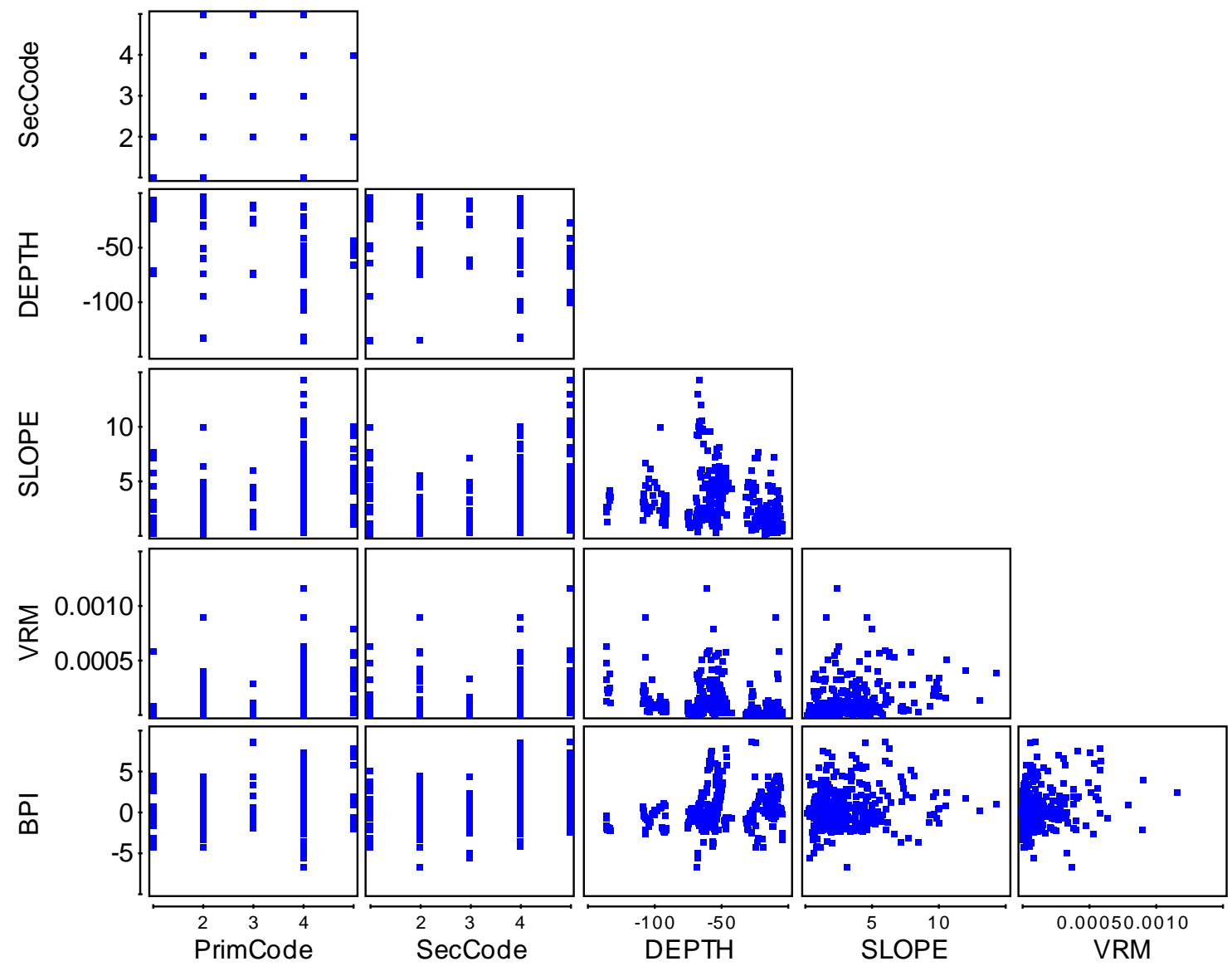

Figure 12. Draftsman plot showing correlations between the six physical variables. Correlation coefficients are given in table 3. Abbreviations: Primcode, Primary substrate (Tissot and others, 2006); SecCode, secondary substrate (Tissot and others, 2006); VRM, Vector Ruggedness Measure (Sappington and others, 2007), BPI, Bathymetric Position Index (Wright and others, 2012). 
Table 3. Correlations between physical variables in the Admiralty Inlet map area. Abbreviations: Primcode, Primary substrate (Tissot and others, 2006); SecCode, secondary substrate (Tissot and others, 2006); VRM, Vector Ruggedness Measure (Sappington and others, 2007); BPI, Bathymetric Position Index (Wright and others, 2012).

$\begin{array}{cccccc} & \text { PrimCode } & \text { SecCode } & \text { Depth } & \text { Slope } & \text { VRM } \\ \text { SecCode } & 0.63 & & & & \\ \text { Depth } & -0.62 & -0.49 & & & \\ \text { Slope } & 0.39 & 0.39 & -0.33 & & \\ \text { VRM } & 0.33 & 0.26 & -0.35 & 0.38 & \\ \text { BPI } & 0.01 & 0.10 & 0.22 & 0.12 & 0.18\end{array}$

Physical data in the Admiralty Inlet map area clustered much more readily, and into a smaller number of groups than areas to the south, largely because of the much smaller range of values for slope (0.02-20 versus $0.12-66)$ and BPI (-7-8 versus -63-35) compared to areas to the south. This in turn likely relates to the relative prevalence of bedrock to the south versus the Admiralty Inlet map area samples, with the rocky-habitat samples varying highly in slope and topography. At the $\mathrm{p}=0.01$ level, the physical observations clustered into 9 groups, lettered a-i, in fig. 13). As with the biota, physical data groups varied greatly in inter-group sample quantity and diversity. 


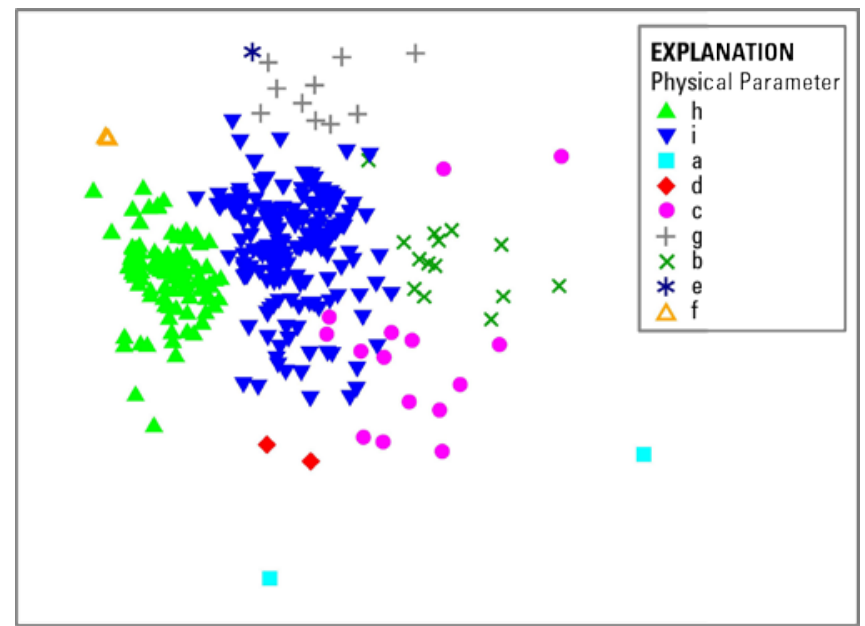

Figure 13. Multidimensional scaling plot of the six physical parameters (table 3 ) at the $p=0.01$ level in Admiralty Inlet map area. Five outlier samples were omitted.

The figure 13 MDS plot of the sample points of data for the six physical parameters (table 3) resymbolized with the biological cluster group occupying each sample (fig. 14) show that, in some cases, samples that are similar (group closely together) physically are also similar biologically (fall into the same biological cluster); for example biological clusters $d$ and e are on the left side, cluster $\mathrm{j}$ on the right.

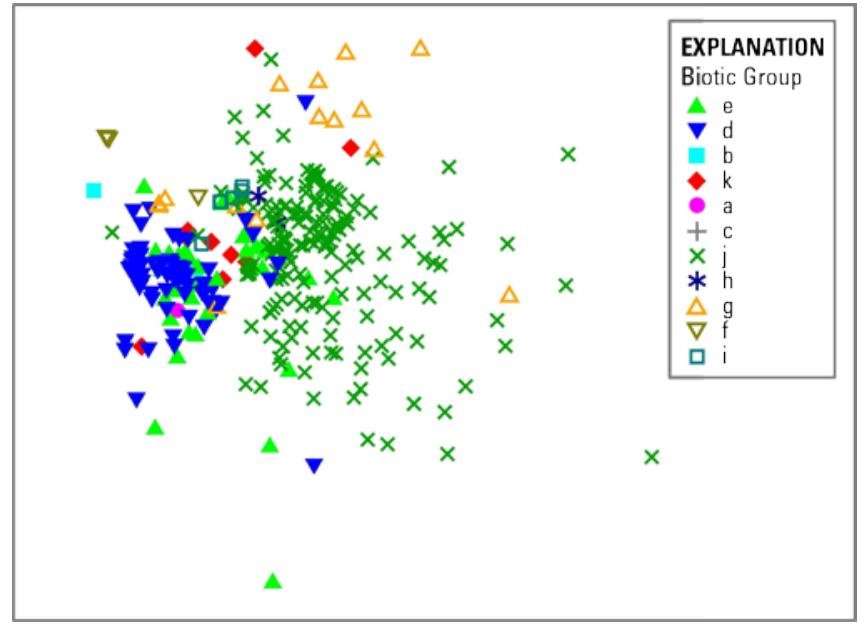

Figure 14. Multidimensional scaling plot of physical parameters in Admiralty Inlet map area samples, with each sample coded by biological cluster group (described in table 2) identified in the clustering routine (at the $p=0.01$ level). 


\section{CMECS Classification}

By Guy R. Cochrane, Megan N. Dethier, and Timothy O. Hodson

The nature of the biological data gathered makes it difficult to define clear biotopes. It was difficult to see or identify many organisms in the video; with an average of only 3-4 taxa per sampling unit, it is hard to characterize biotic assemblages. Some biological clusters of taxa were identified statistically for multiple map areas, and within each area, some of these groupings were found at consistent depths and (or) with predictable substrates. The maps are not fine-grained enough to capture the physical variation seen within one-minute video units. The biological data suggest that to some degree these combinations of physical parameters correspond to biotopes, in other words, that there is some level of predictability about the associations of plants and animals that will be found with different combinations of geological and oceanographic parameters. The map would be improved if data on water chemistry (salinity) and energy (currents) could be included. To really define biotopes, however, it is likely that a method capable of capturing smaller and infaunal biota is needed. Much of the diversity of subtidal organisms in Puget Sound consists of small organisms living in the sediment, so that video observations capturing primarily large and colorful taxa are limited in their ability to quantify the elements really needed to map the biotic communities and relate them to physical features. The groupings in the Admiralty Inlet map did not bear any resemblance to groupings to the south. Given that the substrates in the Admiralty Inlet map area were quite different from the southern areas, this differentiation is not surprising.

The Admiralty Inlet map area contained different biological assemblages than map areas to the south, although many of the overall patterns held in terms of importance of particular physical parameters. Taxa notably more common included barnacles, all types of algae (green, brown, red, and Laminarians), scallops, and urchins. Taxa notably less common were cerianthid anemones, ratfish, the seastar Mediaster, the anemone Metridium, and flatfish and rockfish. A PRIMER 6 BEST test was used to enumerate the physical parameters that are the best predictors of the biological groupings or assemblages. The best overall predictor of biotic assemblage structure was a combination of two variables, depth and primary substrate type, and the relation between the two. The best predictive combination of three variables was primary substrate type, secondary substrate, and depth (rho $=0.55$ ), and of four variables was depth, slope, and primary and secondary substrate types ( $r h o=0.49$ ). Inclusion of VRM and BPI never improved the rank correlation. Thus, the data consistently show that depth and substrate types are the best predictors of biotic assemblages. The VRM parameter may have been reduced in usefulness by the variability of data resolution in the various sonar surveys used (see GroundTruth Studies for the Admiralty Inlet Map Area). BPI values used in this analysis were based on the methodology of Young and others (2010), which was developed for rockfish studies in nonglacial California waters. Puget Sound is a glacially formed landscape and the geomorphology differs significantly from that of the California continental shelf. An entirely separate effort to develop useful BPI scaling for Puget Sound might be fruitful but is not part of this study.

Many of the surveyed sites seem to fit within a few CMECS categories, although most of its categories do not have clear definitions. The current sampling was entirely done in:

Ecoregion $=$ Puget Trough

Estuarine or Marine?; Admiralty Inlet is on the border of what some would call Marine (for example, Dethier 1990) - without a clear CMECS definition, it is impossible to know how to categorize this area.

Subtidal (all)

Consolidated (bedrock): seen in map areas to the south, but not in the Admiralty Inlet map area. Unconsolidated bottom: high variation found within this category. 
The CMECS system then becomes nonhierarchical, describing finer details of the physical environment in terms of attributes, none of which have defined categories:

Enclosure: most of our samples were Unenclosed (open, not in bays)

Energy type = current, surface waves, and tides: most probably high energy

Tide range: moderate to high

Primary water source: probably marine

Profile: low?

Slope: low to moderate?

Rugosity: low to moderate?

Anthropogenic impact: none (or minimal)

The best overall predictors of biotic assemblage, depth and substrate type, were used to generate the CMECS biotope map (sheet 4). CMECS substrate subclass was used for substrate type as it was the only substrate variable established for the entire map area. Depth zones in the biotope map are based on Dethier (1992). Substrate subclass polygons generated for sheet 3 were intersected with depth zone boundary contours derived from the bathymetry (sheet 1). The resulting intersection polygon shapefile is published in the USGS Data Series associated with this project (Cochrane, 2015). 


\section{References Cited}

Anderson, T.J., Cochrane, G.R., Roberts, D.A., Chezar, H., and Hatcher, G., 2007, A rapid method to characterize seabed habitats and associated macro-organisms, in Todd, B.J., and Greene, H.G., eds., Mapping the seafloor for habitat characterization: Geological Association of Canada Special Paper 47, p. 71-79.

Barrio Frojan, C.R.S., Bolam, S.G., Eggleton, J.D., and Mason, C., 2012, Large-scale faunal characterisation of marine benthic sedimentary habitats around the U.K.: Journal of Sea Research, v. 69, p. 53-65.

Brown, C.J., Smith, S.J., Lawton, P., and Anderson, J.T., 2011, Benthic habitat mapping-a review of progress towards improved understanding of the spatial ecology of the seafloor using acoustic techniques: Estuarine, Coastal and Shelf Science, v. 92, p. 502-520.

Cannon, G.A., 1983, An overview of circulation in the Puget Sound estuarine system: National Oceanic and Atmospheric Administration Technical Memorandum ERL PMEL-48, available at http://www.pmel.noaa.gov/pubs/PDF/cann593/cann593.pdf.

Carpenter, R., Peterson, M.L, and Bennett, J.T, 1985, 210Pb derived sediment accumulation and mixing rates for the Greater Puget Sound Region: Marine Geology, v. 64, p. 291-312.

Clague, J.J., 1981, Late Quaternary geology and geochronology of British Columbia; Part 2-Summary and discussion of radiocarbon-dated Quaternary history, Geological Survey of Canada, Paper 80-35, 41 p., doi:10.4095/119439.

Clague, J.J., Harper, J.R., Hebda, R.J., and Howes, D.E., 1982, Late Quaternary sealevels and crustal movements, coastal British Columbia: Canadian Journal of Earth Science, v. 19, p. 597-618.

Cochrane, G.R., compiler, 2015, Data Catalog for CMECS Habitat mapping in the Southern Salish Sea, U.S. Geological Survey Data Series 935, http://pubs.usgs.gov/ds/935/.

Connor, D.W., Allen, J.H., Golding, N., Howell, K.L., Lieberknecht, L.M., Northen, K.O., Reker, J.B., 2004, The marine habitat classification for Britain and Ireland, version 04.05: Joint Nature Conservation Committee, at www.jncc.gov.uk/MarineHabitatClassification.

Cowardin, L.M., Carter, V., Golet, F.C., and LaRoe, E.T., 1979, Classification of wetlands and deepwater habitats of the United States: U.S. Department of the Interior, Fish and Wildlife Service FWS/OBS-79/31, 131 p.

Dethier, M.N., 1992, Classifying marine and estuarine natural communities; an alternative to the Cowardin system: Natural Areas Journal, v. 12, no. 2, p. 90-100.

Dethier, M.N., and Harper, J., 2012, Classes of nearshore coasts, chap. 4 of Simenstad, C., and Yanagi, T., eds., Classification of estuarine and nearshore coastal ecosystems, vol. 1 in Wolanski, E., and McLusky, D.S., eds., Treatise on Coastal and Estuarine Science: Elsevier, Academic Press, Waltham, Mass., p. 61-74.

Dethier, D.P., Pessl, F., Jr., Keuler, R.F., Balzarini, M.A., and Pevear, D.R., 1995, Late Wisconsinan glaciomarine deposition and isostatic rebound, northern Puget Lowland, Washington: Geological Society of America Bulletin, v. 107, p. 1288-1303.

Ebbesmeyer, C., and Cannon, G.A., 2001, Brightwater marine outfall siting study review-Puget Sound physical oceanography related to the Triple Junction region: King County Department of Natural Resources KCR 796, 34 p.

Finlayson, D.P., 2005, Combined bathymetry and topography of the Puget Lowland, Washington State: University of Washington School of Oceanography Data Archives PSDEM2005, available at http://www.ocean.washington.edu/data/pugetsound/. 
Freitas, R., Ricardo, F., Pereira, F., Sampaio, L., Carvalho, S., Gaspar, M., Quintino, V., and.Rodrigues, A.M., 2011, Benthic habitat mapping-Concerns using a combined approach (acoustic, sediment and biological data): Estuarine, Coastal and Shelf Science, v. 92, p. 598-606.

Greene, H.G., Yoklavich, M.M., Starr, R.M., O’Connell, V.M., Wakefield, W.W., Sullivan, D.E., McRae, J.E., Jr., and Caillet, G.M., 1999, A classification system for deep seafloor habitats:

Oceanologica Acta, v. 22, p. 663-678.

Herzer, R.H., and Bornhold, B.D., 1982, Glaciation and post-glacial history of the continental shelf off southwestern Vancouver Island, British Columbia: Marine Geology, v. 48, p. 285-319.

Hewitt, A.T., and Mosher, D.C., 2001, Late Quaternary stratigraphy and seafloor geology of eastern Juan de Fuca Strait, British Columbia and Washington: Marine Geology, v. 177, no. 3, p. 295-316.

Johnson, S.Y., Rhea, S.B., Dadisman, S.V., Mosher, D.C., 2001, Depth to the base-of-Quaternary in the eastern Juan de Fuca Strait region, in Mosher, D.C., and Johnson, S.Y., eds., Rathwell, G.J., Kung, R.B., and Rhea, S.B., compilers, Neotectonics of the Eastern Juan de Fuca Strait; A Digital Geological and Geophysical Atlas: Geological Survey of Canada Open File Report D393.

Keefer, M.L., Peery, C.A., Wright, N., Daigle, W.R., Caudill, C.C., Clabough, T.S., Griffith, D.W., and Zacharias, M.A., 2008, Evaluating the NOAA coastal and marine ecological classification standard in estuarine systems_-A Columbia River Estuary case study: Estuarine, Coastal and Shelf Science, v. 78, p. 89-106.

Lavelle, J.W., Massoth, G.J., and Crecelius, E.A., 1985, Sedimentation rates in Puget Sound from 210pB measurements: National Oceanic and Atmospheric Administration Technical Memorandum ERL PMEL-61, available at http://www.pmel.noaa.gov/pubs/PDF/lave732/lave732.pdf.

Lavelle, J.W., Mofjeld, H.O., Lempriere-Doggett, E., Cannon, G.A., Pashinski, D.J., Cokelet, E.D., and Lytle, L., 1988, A multiply-connected channel model of tides and tidal currents in Puget Sound, Washington and a comparison with updated observations, National Oceanic and Atmospheric Administration Technical Memorandum ERL PMEL-84, 103 p., available at http://docs.lib.noaa.gov/noaa_documents/OAR/PMEL/TM_ERL_PMEL/TM_ERL_PMEL_84.pdf. Linden, R.H., and Schurrer, P.J., 1988, Sediment characteristics and sealevel history of Royal Roads Anchorage, Victoria, British Columbia: Canadian Journal of Earth Science, v. 25, p. 1800-1810. Madden, C.J., Goodin, K., Allee, R.J., Cicchetti, G., Moses, C., Finkbeiner, M., and Bamford, D., 2009, Coastal and marine ecological classification standard, version 3: National Oceanic and Atmospheric Administration and NatureServe, 126 p., http:/coast.noaa.gov/digitalcoast/publications/cmecs/

Matsuura, H., and Cannon, G.A., 1997, Wind effects on sub-tidal currents in Puget Sound: Journal of Oceanography, v. 53, no. 1, p. 53-66.

Mosher, D.C., and Hewitt, A.T., 2004, Late Quaternary deglaciation and sea-level history of eastern Juan de Fuca Strait, Cascadia: Quaternary International, v. 121, no. 1, p. 23-39.

National Oceanic and Atmospheric Administration, 2002a, National Oceanic and Atmospheric

Administration Form 76-35A, Descriptive Report, Hydrographic, Registry Number H-11188: National Geophysical Datacenter, at ftp://ftp.ngdc.noaa.gov/pub/coast/H10001-

H12000/H11188/DR/H11188.pdf.

National Oceanic and Atmospheric Administration, 2002b, National Oceanic and Atmospheric

Administration Form 76-35A, Descriptive Report, Hydrographic, Registry Number H-11040: National Geophysical Datacenter, at ftp://ftp.ngdc.noaa.gov/pub/coast/H10001-

H12000/H11040/DR/H11040.pdf.

National Oceanic and Atmospheric Administration, 2002c, National Oceanic and Atmospheric Administration Form 76-35A, Descriptive Report, Hydrographic, Registry Number H-11039: National Geophysical Datacenter, at ftp://ftp.ngdc.noaa.gov/pub/coast/H10001H12000/H11039/DR/H11039.pdf. 
National Oceanic and Atmospheric Administration, 2002d, National Oceanic and Atmospheric Administration Form 76-35A, Descriptive Report, Hydrographic, Registry Number H-11038: National Geophysical Datacenter, at ftp://ftp.ngdc.noaa.gov/pub/coast/H10001-

H12000/H11038/DR/H11038.pdf.

National Oceanic and Atmospheric Administration, 2009, National Oceanic and Atmospheric Administration Form 76-35A, Descriptive Report, Hydrographic, Registry Number H-11801: National Geophysical Datacenter, at ftp://ftp.ngdc.noaa.gov/pub/coast/H10001-

H12000/H11801/DR/H11801.pdf.

National Oceanic and Atmospheric Administration, 2010, Benthic Terrain Modeler: National Oceanic and Atmospheric Administration Digital Coast, at http://csc.noaa.gov/digitalcoast/tools/btm.

Newton, J.A., Siegel, E., and Albertson, S.L., 2003, Oceanographic changes in Puget Sound and the Strait of Juan de Fuca during the 2000-01 drought: Canadian Water Resources Journal, v. 28, no. 4, p. 715-728.

Nittrouer, C.A., Sternberg, R.W., Carpenter, R., and Bennett, J.T., 1979, The use of Pb-210 geochronology as a sedimentological tool-Application to the Washington continental shelf: Marine Geology, v. 31, p. 297-316.

Porter, S.C., and Swanson, T.W., 1998, Radiocarbon age constraints on rates of advance and retreat of the Puget Lobe of the Cordilleran Ice Sheet during the last glaciation: Quaternary Research, v. 50, p. 205-213.

Sappington, J.M., K.M. Longshore, and D.B. Thomson. 2007, Quantifiying Landscape Ruggedness for Animal Habitat Analysis: A case Study Using Bighorn Sheep in the Mojave Desert. Journal of Wildlife Management. 71(5): 1419-1426.

Schoch, G.C., and Dethier, M.N., 1996, Scaling up-The statistical linkage between organismal abundance and geomorphology on rocky intertidal shorelines: Journal of Experimental Marine Biology and Ecology, v. 201, p. 37-72.

Stolt, M., Bradley, M., Turenne, J., Payne, M., Scherer, E., Cicchetti, G., Shumchenia, E., Guarinello, M., King, J., Boothroyd, J., Oakley, B., Thornber, C., and August, P., 2011, Mapping shallow coastal ecosystems-A case study of a Rhode Island lagoon: Journal of Coastal Research, v. 27, p. 1-15.

Thomson, R.E., 1994, Physical oceanography of the Strait of Georgia-Puget Sound-Juan de Fuca Strait system, in Wilson, R., Beamish, R., Aitkens, F., and Bell, J., eds., Review of the marine environment and biota of Strait of Georgia, Puget Sound and Juan de Fuca Strait: Proceedings of the British Columbia/Washington Symposium on the Marine Environment, p. 36-100.

Tissot, B.N., Yoklavich, M.M., Love, M.S., York, K., and Amend, M., 2006, Benthic invertebrates that form habitat on deep banks off southern California, with special reference to deep sea coral: Fishery Bulletin, v. 104, p. 167-181.

Trusel, L.D., Cochrane, G.R., Etherington, L.L., Powell, R.D., and Mayer, L.A., 2010, Marine benthic habitat mapping of Muir Inlet, Glacier Bay National Park and Preserve, Alaska, with an evaluation of the Coastal and Marine Ecological Classification Standard III: U.S. Geological Survey Scientific Investigations Map 3122, 4 sheets, various scales, 1 pamphlet, 26 p., available at http://pubs.usgs.gov/sim/3122/.

U.S. Geological Survey, 1995, USGS CMG G-3-95-PS: U.S. Geological Survey Coastal and Marine Geology Infobank, at http://walrus.wr.usgs.gov/infobank/g/g395ps/html/g-3-95-ps.meta.html.

U.S. Geological Survey, 1997, USGS CMG G-2-97-PS Metadata: U.S. Geological Survey Coastal and Marine Geology Infobank, at http://walrus.wr.usgs.gov/infobank/g/g297ps/html/g-2-97-ps.meta.html.

U.S. Geological Survey, 2008, USGS CMG K-1-08-WO Metadata: U.S. Geological Survey Coastal and Marine Geology Infobank, at http://walrus.wr.usgs.gov/infobank/k/k108wo/html/k-1-08wo.meta.html. 
U.S. Geological Survey, 2008, USGS CMG T-1-08-PS Metadata: U.S. Geological Survey Coastal and Marine Geology Infobank, at http://walrus.wr.usgs.gov/infobank/t/t108ps/html/t-1-08-ps.meta.html.

Van Cleve, F.B., 2009, Marine protected areas in Washington-Recommendations of the Marine Protected Areas Work Group to the Washington State Legislature: Washington Department of Fish and Wildlife, available at http://wdfw.wa.gov/publications/00038/wdfw00038.pdf.

Washington State Seafloor Mapping Workshop Steering Committee, 2008, Washington State Seafloor Mapping Workshop Proceedings: Department of Ecology, State of Washington, available at http://www.ecy.wa.gov/programs/sea/ocean/pdf/WA_seafloor_proceedings_final.pdf.

Wright, D.J., Pendleton, M., Boulware, J., Walbridge, S., Gerlt, B., Eslinger, D., Sampson, D., and Huntley, E. 2012, ArcGIS Benthic Terrain Modeler (BTM), v. 3.0, Environmental Systems Research Institute, NOAA Coastal Services Center, Massachusetts Office of Coastal Zone Management, available at http://esriurl.com/5754.

Young, M.A., Iampietro, P.J., Kvitek, R.G., and Garza, C.D., 2010, Multivariate bathymetry-derived generalized linear model accurately predicts rockfish distribution on Cordell Bank, California, USA: Marine Ecology Progress Series 415, p. 247-261. 